\title{
Prehistoric Coastal Mass Burials: Did Death Come in Waves?
}

\author{
Genevieve Cain ${ }^{1}$ (D) - James Goff ${ }^{2,3}$. \\ Bruce McFadgen ${ }^{4}$
}

Published online: 13 July 2018

(C) The Author(s) 2018

\begin{abstract}
Recent large tsunamis in the twenty-first century have provided graphic reminders of the catastrophic impacts such natural hazards can have upon coastal communities. Death tolls in the thousands give rise to the rapid adoption of coastal mass burials for the interment of the dead. While recognised as a necessary practice in the aftermath of such contemporary tragedies, the paucity of coastal mass burial sites related to earlier tsunamis reported in the archaeological record is unusual. We establish a suite of criteria for identifying the geological and archaeological evidence of inundation by past tsunamis and review case studies from two well-documented prehistoric coastal mass burial sites in the Southern Hemisphere (Solomon Islands and Vanuatu). To varying degrees, both sites possess numerous characteristics that suggest direct correlation with previously reported catastrophic palaeotsunamis. In the Northern Hemisphere, we investigate palaeotsunami inundation as an alternative hypothesis for mass burial sites in Orkney and Shetland, a relatively tectonically inactive region where such an association is unlikely to have ever been considered. The nature, chronology and location of these mass burial sites fit well with the proposed archaeological evidence for palaeotsunami inundation, and they also appear to be contemporaneous with the as-yet poorly documented Garth tsunami ( $\sim 5500$ years BP). We suggest that a potentially key diagnostic criterion for determining a palaeotsunami linkage is the use of diatom testing on skeletal remains to establish whether death was caused by drowning in saltwater, a test which has never been applied in this context.
\end{abstract}

Genevieve Cain

genevieve.cain@kellogg.ox.ac.uk

1 Department for Continuing Education, University of Oxford, 1 Wellington Square, Oxford OX1 2JA, UK

2 PANGEA Research Centre, School of Biological, Earth and Environmental Sciences, UNSW Sydney, Sydney, NSW 2052, Australia

3 CNRS, Laboratoire Chrono-Environnement, Université de Bourgogne-Franche-Comté, 25030 Besançon Cedex, France

4 Victoria University of Wellington (VUW), 48 Kelburn Parade, Wellington 6012, New Zealand 
KeywordsPalaeotsunami · Mass burial · Prehistoric · Solomon Islands · Vanuatu · Orkney Shetland · Garth

\section{Introduction}

Numerous mass burial sites have been reported by archaeologists from around the world such as the recently discovered Viking-Age example from the Ridgeway Hill Burial Pit in the UK (Loe et al. 2014) and the Early Neolithic massacre-related mass grave of Schöneck-Kilianstädten in Germany (Meyer et al. 2015). With evidence of decapitation, blunt force trauma and/or weapon injuries, such burials can readily be assigned to violent deaths associated with warfare. However, in the absence of clear signs of warfare, the raison d'etre for such mass burials is often difficult to determine.

When a historical record is available, the reason for mass burial may be determined not only by a forensic study of the remains themselves but also by comparison with documentary evidence and sometimes oral histories (e.g. Minami et al. 2012; Dudley et al. 2011; King and Goff 2010). This has led to a growing recognition of historical mass burials related to natural disasters particularly in countries such as Japan that are exposed to a suite of climatic and tectonic-related hazards such as typhoons, earthquakes and tsunamis (e.g. Goff and Sugawara 2014). However, such causes are rarely, if ever, considered for prehistoric coastal mass burials.

Of particular note in this respect is the growing ability of researchers to identify the occurrence of prehistoric tsunamis (palaeotsunamis) using a suite of geological, archaeological and anthropological techniques. This has been aided by the numerous parallels that can now be drawn between past events and recent historical examples such as the 2004 Indian Ocean (2004 IOT) and 2011 Tohoku-oki (2011 ToT) tsunamis with geological evidence extending multiple kilometres inland. For example, there is a substantial body of research showing that the prehistory of regions such as the Pacific have been punctuated by catastrophic tsunamis (e.g. Goff et al. 2011a and references therein). These events are purported to have caused death, abandonment of coastal settlements, movement of people both inland and uphill, widespread loss of coastal resources, loss of technologies, onset of warfare, breakdown of trading routes, and in some cases the development of event-related rituals and oral histories (e.g. Goff and Nunn 2016; Goff et al. 2012a; Matsumoto et al. 2012; McFadgen 2007; McMillan and Hutchinson 2002).

These or similar effects have also been noted in recent events such as a movement inland and uphill, and the almost total abandonment of coastal areas affected by the 2011 ToT (Kondo 2018). While several years later there is already a partial reoccupation of inundated areas, this is only being achieved through a massive engineering effort with reconstruction over the 10-year period from 2011 to 2020 being estimated to cost US\$285 billion (Suppasri et al. 2012). It is notable that recent research by Japanese tsunami archaeologists following the 2011 ToT has revealed similar human movements after inundation of the same region by a tsunami 2000 years ago. Over the next 400 years, people gradually moved back onto the low-lying coastal lands only to suffer the same fate once again when the 869 AD Joggan tsunami inundated the region (Saino 2015).

There are two fundamental lessons to learn from the Japanese example. First, unlike other potentially catastrophic saltwater inundations such as cyclones (also known as 
hurricanes or typhoons), the long recurrence interval between major tsunamis places such events outside the generational memory of personal experience and as such reduces its significance for prioritising choices for day-to-day life. Second, while cyclones are often cited as equally potentially catastrophic, both geological and contemporary records indicate that even in the most extreme cases (e.g. 2013 Typhoon Haiyan), these rarely inundate inland more than several hundred metres inland (Brill et al. 2016). Furthermore, such events are associated with meteorological conditions that can provide ample warning (hours to days) of an impending cyclone. Catastrophic tsunamis such as the 2004 IOT inundate the land over far greater distances and arrive with little or no warning. Therefore, while acknowledging that events such as cyclones have the potential to cause significant loss of life, given the unexpectedness and magnitudes of past tsunamis, it is far more likely that these will result in a larger death toll.

In this paper, we examine examples of prehistoric coastal mass burial sites from Northern and Southern Hemisphere locations in both tectonically active and relatively inactive zones (Fig. 1). For the purposes of this paper, the term 'prehistoric' will simply refer to the time before written record, which varies greatly by region; oral histories will be discussed where relevant. The term 'burial' will refer to both inhumations and also the placement of human remains in above ground locations (e.g. tombs).

\section{Context}

\section{Tsunamis}

Tsunamis are waves generated by a variety of processes, including earthquakes (e.g. Japan, 2011; magnitude 9.0: Goto et al. 2011), slope failures such as landslides into water (e.g. Lituya Bay, Alaska; slide volume $0.03 \mathrm{~km}^{3}$ : Fritz et al. 2009) and those

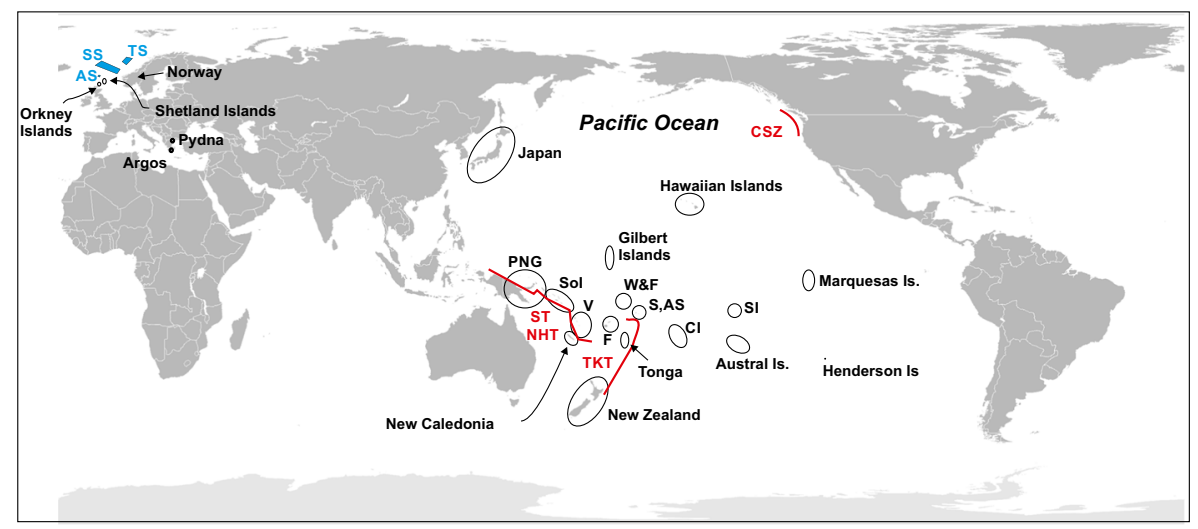

Fig. 1 World map showing key sites mentioned in the text. Approximate locations are given as follows: Red lines are relevant subduction zone $(\mathrm{CSZ}=$ Cascadia subduction zone; NHT $=$ New Hebrides trench; $\mathrm{ST}=$ Solomons trench; TKT = Tonga Kermadec trench); blue shaded areas are key submarine slope failures (AS = Afen slide; $\mathrm{SS}=$ Storegga slide; $\mathrm{TS}=$ Trænadjupet Slide); open black circles and ellipses are countries, islands and island archipelagos (CI = Cook Islands; F = Fiji; PNG = Papua New Guinea; S,AS = Samoa, American Samoa; SI = Society Islands; SoI = Solomon Islands; V = Vanuatu; W\&F = Wallis and Futuna) 
beneath the water (e.g. Trænadjupet slide; volume 500-100 $\mathrm{km}^{3}$ : Løvholt et al. 2017) that may or may not be generated by tectonic-related processes (Yamada et al. 2012), and volcanic eruptions. Tsunamis can therefore occur in relatively tectonically inactive regions and recent examples include small volume slope failures such as the 1979 Nice Harbour, France (slide volume $\left.0.009 \mathrm{~km}^{3}\right)$ and 1996 Finneidfjord, Norway $\left(0.001 \mathrm{~km}^{3}\right)$ events that killed eight and four people, respectively (Dan et al. 2007; Longva et al. 2003; Sahal and Lemahieu 2011).

Once a tsunami has been generated, it moves away from the source area as a series of fast-moving waves. In the deep ocean, tsunami waves can travel up to $900 \mathrm{~km} \mathrm{~h}^{-1}$, with a wave height of only about $0.5 \mathrm{~m}$, a wavelength greater than $150 \mathrm{~km}$ and wave periods up to 120-150 min (as opposed to max. storm wave characteristics around 50+ $\mathrm{km} \mathrm{h}^{-1}$ speed, $100 \mathrm{~s}$ of $\mathrm{m}$ wavelength and 15-20 s wave period). Approaching the coast, the sea gets shallower, frictional drag increases, the wavelength decreases and waves increase in height. Unlike storms, the long wavelengths and wave period ensure that tsunamis can expend their immense energy across a considerable distance inland.

Even in the most tectonically active parts of the world, the return periods for large tsunamis are in the order of 250-500 years at best. In less tectonically active areas, significant sources are generally limited to some form of landslide and return periods often exceed 1000 s of years. Unlike storms therefore, their unpredictability and long return periods leave most contemporary coastal human populations unprepared for a hazard that is either poorly understood or unknown. Japan, probably the most tsunamiprepared country in the world, has a term for such events, souteigai-tsunamis or unexpectedly large (Goff et al. 2014). The 2004 IOT was just such an event, causing the deaths of around a quarter of a million people (Alam et al. 2012). While there are rare instances of preparedness embedded within oral traditions (e.g. McAdoo et al. 2006) and population movement inland (Saino 2015), no archaeological evidence has been presented concerning mass deaths from tsunamis.

\section{Mass Burials and Historical Tsunamis}

Recent catastrophic tsunamis provide examples of post-disaster mortuary practices in the face of an overwhelming number of dead. In the immediate aftermath of an event, there are usually attempts to bury individuals in culturally appropriate manners, but mass burial soon becomes the norm (Phillips et al. 2008). Until recently, when mechanical diggers became available, mass burials were usually dug manually as shallow trenches or pits $(<1.0 \mathrm{~m}$ deep), or beneath mounds of stones or debris (Morgan et al. 2006).

While some communities have used existing cemeteries for siting mass graves, they are predominantly situated in convenient coastal locations closest to the largest number of bodies (Morgan et al. 2006). Mass burials generally have two types of body arrangement, either with bodies in layers or in an unstructured manner (Phillips et al. 2008). Both types of arrangements can lead to the comingling of bodies and, subsequently, skeletal remains (Morgan et al. 2006). In the case of the 2004 IOT, there were 14 mass graves in Banda Aceh alone, with the largest containing 60,000-70,000 bodies (Morgan et al. 2006). Death rates in coastal communities can be high-the 1896 AD Sanriku tsunami killed up to $83 \%$ of the population of some villages (Smits 2011). Faced with an overwhelming number of dead (and few survivors) in the early stages of 
post-tsunami recovery, delays in interring all of the victims often lead to animals feeding on the corpses, causing variable amounts of dismemberment of the bodies (Rutty et al. 2005).

The historically documented 1293 AD Kamakura, Japan earthquake/tsunami (1293 KJT) is at the cusp of written history, and as such, the discovery and interpretation of an associated mass burial site provides a useful archaeological perspective. Geological evidence for the tsunami is evident in the region (Iida 1984) and written accounts of the event in Kamakura Oh Nikki and Azuma Kagami state that 20,000-30,000 people died, with the bodies of humans, cows, horses, fish, dolphins and whales filling the roads (Minami et al. 2012). The earthquake/tsunami left the Kamakura region isolated and in ruins and as a result many of the dead were not buried immediately.

Work on the mixed human-animal mass burial site at the coastal town of Yuigahama-minami recovered 3108 human skeletons with radiocarbon dating confirming that they had been buried during a short period of intensive site use (Minami et al. 2012). Many skeletons had dog bite marks suggesting that corpses had been exposed for considerable time after death, with body parts scattered by dogs and other scavengers (Nagaoka and Hirata 2006). Fragmentary skeletons were buried together. Most of the animals were undoubtedly also tsunami victims since Medieval Kamakura Buddhist practices limited the eating of terrestrial animal meat and there was also no custom of whaling (Minami et al. 2012).

In addition to the mixed human-animal mass burial, 667 human skeletons were also excavated from individual burials and most, but not all, are also considered to be victims of the $1293 \mathrm{KJT}$ (Minami et al. 2012). The general age distribution mirrors that of the population at the time with a little over $1 \%$ having sword cut marks.

While these historical findings show some regional variations, there are significant areas of commonality associated with mass burials in response to a devastating tsunami (Table 1). Notably, mass burials tend to be found at or near the coast, most likely in an area where the number of bodies is at their most dense. Some individual burials may occur but most take place with little or no thought to cultural sensitivities. The causes of death vary but normally include asphyxiation (as sediment carried in the tsunami is pushed into the lungs by the force of water), followed by drowning, impact injuries and wound infections (Keim 2006; Phillips et al. 2008). Warfare/defence injuries may be noted on some skeletons, but these should not be seen as being diagnostic of a mass war grave, rather as reflecting the nature of the general population at the time.

In historical examples, there is little reason to mention the association of the tsunami deposit with the mass burials, although there is a considerable body of geological evidence to this effect (e.g. 2004 IOT: Liu et al. 2005; 1896 AD Sanriku: Yagishita 2001; 1293 KJT: Iida 1984). This raises an important point: finding palaeotsunami evidence that is potentially contemporaneous with a coastal mass burial(s) is an important step in establishing a possible link between the two.

\section{Identifying Palaeotsunamis and Their Effects on Humans}

Palaeotsunami research is a relatively young discipline which started around the mid1980s with the ground-breaking geological work of Atwater (1987) who studied the 1700 AD Cascadia subduction zone (CSZ in Fig. 1) earthquake/palaeotsunami. Since then, the discipline has grown significantly with numerous geological proxies being 
Table 1 Summary of potential palaeotsunami-related mass burial characteristics based upon historically documented events

Characteristic

1. Rapid burial usually with little/no consideration of cultural sensitivities

2. Often associated with some individual burials (either early attempts to follow ritual, or burial of high-status individuals)

3. Burial in shallow trenches or pits (often $<1.0 \mathrm{~m}$ deep) or under mounds of stones or debris

4. Use of existing burial sites and/or closest to largest number of bodies - tend to be found at or near the coast

5. Body arrangement either in a 'rack system' with bodies laid facing one direction (or in alternating directions for each layer) or in an unstructured manner

6. Comingling of bodies and, subsequently, skeletal remains can occur

7. Sometimes divided into sections (e.g. separate area for children)

8. Animals may feed on corpses causing variable amounts of dismemberment of the bodies (either pre- or post-inhumation). Often fragmentary skeletons buried together

9. Mass burial may include animals/fish killed in the same event

10. Since death is usually by asphyxiation, drowning, impact injuries and wound infections, skeletal remains may not show visible signs of tsunami trauma

11. Radiocarbon (or other) dating invariably indicates burials occurred during a short period of intensive site use as opposed to a specific date. Individual burials before or after mass burial reflect site use over a longer time period

12. General age distribution of skeletons most likely reflects population at the time

13. Warfare/defence injuries may be noted on some skeletons, reflecting the nature of the general population at the time

14. Can be associated with geological evidence for the palaeotsunami- burials may be dug into or mixed with it

15. Local knowledge about potential prehistoric mass burial sites may be preserved in oral histories, or this information may be lost (either too long ago, or possibly due to significant loss of indigenous knowledge caused by large magnitude events. n.b. The absence of oral traditions is not evidence for the absence of an event)

16. Mass burial may be located in, or proximal to, an event-related ritual structure or shrine

used to identify palaeotsunami deposits (Table 2: Goff et al. 2012a). By the time Atwater (1987) reported on his research, anthropologists had already published work referring to Native American oral histories concerning possible palaeotsunamis in the region (Heaton and Snavely 1985). Subsequently, this combination of geological and anthropological work assisted archaeologists in identifying prehistoric coastal village abandonments associated with past Cascadia events (Hutchinson and McMillan 1997).

This early work was important because it indicated that an interdisciplinary approach was needed to fully understand the nature and extent of the $1700 \mathrm{AD}$ palaeotsunami. This point was further developed by Goff et al. (2012a) who identified up to 30 proxies that could be used to help identify a palaeotsunami. These proxies come from the fields of geology, chemistry, biology, archaeology, anthropology and geomorphology, while also recognising the importance of reviewing contextual data-evidence from other sites in the region. Ultimately, not all of the proxies available have ever been used at a single site, but they are all equally relevant. For example, in the absence of any archaeological proxies for tsunami inundation, a selection of geological, chemical and/or biological data could be used. Conversely, in the absence of geological data, 
Table 2 A summary list of palaeotsunami proxies based on 'diagnostic criteria' developed through a series of published iterations. For more details, refer to Chagué-Goff et al. (2011), Goff and McFadgen (2003), Goff et al. (2001, 2012a), McFadgen and Goff (2007), and Morton et al. (2007)

Geological:

1. Particle/grain sizes range from boulders (may be $750 \mathrm{~m}^{3}$ or larger) to fine mud. A tsunami will usually transport whatever size ranges are available - it is sediment source-dependent

2. Sediments generally fine inland and upwards within the deposit but can also have a coarsening upwards component associated with deposition from a traction carpet. Deposits generally rise in altitude and thin inland and can extend for several kilometres inland and 10s or 100s of $\mathrm{km}$ alongshore

3. Each wave can form a distinct sedimentary unit and/or there may be laminated sub-units

4. Distinct lower and upper sub-units representing runup and backwash can sometimes be identified. This is unlike storm or anthropogenic deposits

5. Lower contact is usually unconformable or erosional

6. Can contain intraclasts (rip-up clasts) of reworked material

7. Sometimes associated with loading structures at the base of deposit — and can be associated with liquifaction features on the ground surface caused by earthquake groundshaking

8. Micro-scale features can include micro-rip-up clasts, millimetre-scale banding, organic entrainment, fining-up sequences and erosive contacts that may be visible in thin section but not in field stratigraphy

9. Measurement of magnetic fabric (MF) combined with grain size analysis provides information on hydrodynamic conditions 'typical' during tsunami deposition - essential when no sedimentary structures are visible. Magnetic properties of minerals (incl. magnetic susceptibility) provide information about depositional environment

10. Heavy mineral laminations are often present but are source-dependent. Normally near base of unit/sub-unit but not always. Composition and vertical distribution of heavy mineral assemblage may change from the bottom to the top of the deposit (e.g. often more micas at the top)

Chemical:

11. Increases in elemental concentrations of sodium, sulphur, chlorine (palaeosalinity indicators, including element ratios), calcium, strontium, magnesium (shell, shell hash and coral), titanium and zirconium (associated with heavy mineral laminae if present) occur in tsunami deposits relative to under- and overlying sediments. Indicates saltwater inundation, and/or high marine shell/coral content, and/or high-energy environment (heavy minerals, source-dependent). Preservation issues to be considered in particular for salt (downward leaching), but uptake and preservation can occur in wetlands/soils

12. Possible contamination by heavy metals and metalloids (source-dependent, incl. water depth source)

13. Geochemical (saltwater signature) and microfossil evidence often extends further inland than landward maximum extent of sedimentary deposit

Biological:

14. Individual shells and shell-rich units are often present (shells are often articulated and can be water-worn). Often more intact shells as opposed to shell hash. A wide range of shell ages is indicative of greater reworking by a tsunami as opposed to storm or anthropogenic deposits. Small, fragile shells and shellfish can be found at or near the upper surface of palaeotsunami deposits

15. Shell, wood and less dense debris often found 'rafted' at or near the top of sequence (increase in organic content determined by loss on ignition and sometimes moisture content)

16. Often associated with buried vascular plant material and/or buried soil and/or skeletal (non-human) remains

17. Generally associated with an increase in abundance of marine to brackish diatoms - often a greater percentage of reworked terrestrial diatoms near the upper part of the deposit. Large number of broken valves often observed, reflecting turbulent flows. Variations in diatom affinities often indicative of source areas and magnitude of event

18. Marked changes in foraminifera (and other marine microfossils, such as dinoflagellates, nannoliths) assemblages occur. Deeper water species are introduced - this is unlikely in storm or anthropogenic deposits, and/or increase in foraminifera abundance and breakage of tests. Composition relates to source (near-shore vs. offshore). Foraminifera size tends to vary with grain size 
Table 2 (continued)

19. Pollen concentrations are often lower (diluted) in the deposit because of the marine origin and/or include high percentage of coastal pollen (e.g. mangroves). Pollen changes above and below the deposit are often indicative of sustained environmental change, a critical ecological threshold has been crossed-e.g. infilling or shallowing of coastal wetland

Archaeological:

20. Archaeological sites - a sediment layer (often a discontinuous gravel lag and/or beach/dune sand) separating, underlying or overlying anthropogenic deposits/occupation layers

21. Archaeological middens: marked changes in shellfish species/absence of expected species indicate sudden change in onshore and nearshore palaeoenvironmental conditions

22. Archaeological structures show structural damage by water to buildings/foundations at a site

23. Archaeological burial sites have been reworked, often recognisable as 'culturally inappropriate' burials

24. Replication - coastal archaeological occupation layers and shell middens are often separated or extensively reworked at several sites along coastline giving a regional/national signal of inundation Anthropological:

25. Traditional environmental knowledge (oral histories) from the locality/region Geomorphological:

26. Acquired palaeogeomorphology indicates tsunami inundation-a tsunami geomorphology is present that could include evidence of: (i) uplift or subsidence/compaction of site/locality, (ii) scour/erosion/reworking of sediments at site/locality — altered dune morphology, and (iii) sand sheet or other similar deposits such as gravel deposition/gravel pavements

27. Palaeogeomorphology at the time of inundation indicates low likelihood of storm inundation Contextual:

28. Known local or distant tsunamigenic sources can be postulated or identified

29. Known local and regional palaeoenvironmental drivers indicate low likelihood of storm inundation

30. Replication - similar contemporaneous coastal deposits are found regionally giving a regional signal of inundation

archaeological, anthropological and/or geomorphological proxies are available (Goff et al. 2012a). McFadgen and Goff (2007) provide a more detailed discussion of archaeological proxies (Table 3).

As recently as 2009, many Pacific archaeologists were still of the opinion that rapid-onset natural hazards such as tsunamis were too localised in space and time to be important (Anderson 2009). In their view, such events merely add a layer of complexity to Pacific human history but are not as significant as the long-term impacts associated with climate change and anthropogenic modification (Anderson 2009). This view undoubtedly continues to influence archaeological site interpretations within the SW Pacific and reflects a markedly different approach to research reported from other parts of the region such as Japan (e.g. Saino 2012) and the Pacific Northwest (e.g. Hutchinson and McMillan 1997). This is particularly significant for our understanding of Pacific archaeology in the light of a growing body of evidence for two or three major region-wide palaeotsunamis within the SW Pacific region most likely originating from the Tonga Kermadec trench (Fig. 1). These occurred around 1450-1500 AD (hereafter termed midfifteenth century), 1800-2000 years BP (a smaller event) and 2800-3000 years BP (hereafter termed 2800 years BP) during the time of Polynesian settlement (Goff et al. 2012b). 
Table 3 'Archaeological' proxies for palaeotsunamis using both modern/historical (M) and archaeological (A) examples (adapted after McFadgen and Goff 2007)

Proxies $\quad$ Example

1. Oral histories from the locality

2. Post-event burials (mass or otherwise)

3. Site abandonment-permanent or temporary (often coupled with movement inland and uphill)

4. Resource depletion and/or increased warfare, hillfort construction and/or rise of chiefdoms

5. Middens: change in shellfish species/absence of expected species

6. Structural damage: damage to buildings/foundations at site

7. Geomorphological change

(i) Evidence for uplift of site/locality

(ii) Evidence for subsidence/compaction of site/locality

(iii) Scour/erosion/reworking of sediments at site/locality

(iv) Gravel deposition/gravel pavements

(v) Sediment layer separating or overlying anthropogenic deposits

8. Reworking of anthropogenic material at a site

(i) Occupation layers/shell middens

(ii) Burials

9. Replication at more than one occupation site or in off-site deposits

10. Geological context shows after-effects of local and distant tectonics
2009 South Pacific tsunami (American Samoa)

(Dudley et al. 2011) (M)

D'Urville Island, New Zealand (NZ) (King and Goff 2010) (A)

2004 Indian Ocean tsunami (IOT) (see text for references) (M)

This paper (A)

2011 Tōhoku-oki tsunami, Japan (2100 ToT) (Hirano 2013) (M)

Sendai Plain, Japan (Saino 2012, 2015) (A)

2011 ToT (widespread loss of rice crops: Liou et al. 2012) (M)

Regional NZ (McFadgen 2007) (A)

2011 ToT (change in shellfish availability: Seike et al. 2013) (M)

Palliser Bay, NZ (Goff and McFadgen 2001) (A)

1998 Papua New Guinea (1998 PNGT) tsunami (McSaveney et al. 2000a) (M)

Wairau Lagoon, NZ (McFadgen and Goff 2007) (A)

Wellington region, NZ (Grapes and Downes 1997) (M) Mataora-Wairau Lagoon, NZ (King et al. 2017) (A)

Hawaii, USA (Tilling et al. 1976) (M)

Okarito Lagoon, NZ (Nichol et al. 2007) (A)

1998 PNGT (Gelfenbaum and Jaffe 2003) (M)

Henderson Bay, NZ (Regnauld et al. 2004) (A)

2004 IOT (Thailand) (Szczuciński 2012) (M)

Whangapoua Bay, NZ (Nichol et al. 2003) (A)

1993 Hokkaido Nansei-Oki and 1983 Nihonkai-Chubu tsunami, Japan (Sato et al. 1995) (M)

Okoropunga, NZ (Goff et al. 2004) (A)

2004 IOT (Sri Lanka) (Liu et al. 2005) (M)

Futuna Is, Wallis and Futuna (Goff et al. 2011b) (A)

J. Goff, pers. obs. 2004 IOT (Sri Lanka) (M)

Mataora-Wairau Lagoon, NZ (McFadgen and Goff 2007) (A)

2004 IOT (Sri Lanka) (Liu et al. 2005) (M)

Northland region, NZ (Goff et al. 2010) (A)

Lower Wairau Plains, NZ (Grapes and Goh 1998) (M) Canterbury region, NZ (McFadgen and Goff 2005) (A)

2004 IOT (Sri Lanka) (Liu et al. 2005) (M)

Northland region, NZ (Goff et al. 2010) (A)

Lower Wairau Plains, NZ (Grapes and Goh 1998) (M)

Canterbury region, NZ (McFadgen and Goff 2005) (A) 
With respect to the most recent event, Goff and Nunn (2016) identified rapid societal change (Table 3: points 3, 4 and 9) in Pacific island societies in the fourteenth to fifteenth centuries, recognising this as a proxy for some type of regional environmental forcing. They argued that the driver for such change must have been of an oceanic origin, most likely palaeotsunami, palaeostorm surge or rapid sea-level change. Given the growing body of geological evidence for a mid-fifteenth-century region-wide palaeotsunami, it seems reasonable to suggest that this was the most likely cause.

The recognition of rapid societal change resulting from possible palaeotsunami inundation is not new. Pukapukan oral history (Pukapuka is an island in the northern Cook Islands) refers to a potentially catastrophic palaeotsunami around 1500 AD. It almost completely destroyed all their resources and reduced the island's population to 15 men and two women (Goff et al. 2011a; Sahlins 1957). Many changes in social organisation and land tenure followed this disaster with elements of Polynesian culture recombined into a social structure more attuned to the needs of life on remote Pacific islands (Sahlins 1957). Archaeologists have recorded similar trends on other Pacific islands, such as Ontong Java and Ulawa Island in the Solomon Islands (Goodenough 1955; Hogbin 1931), the Gilbert Islands, the Lau Group (Fiji) and Wallis and Futuna (Goodenough 1955). It is notable that complementary evidence for rapid cultural change is reflected in hillfort construction (Table 3: points 3 and 4) on the Solomon Islands around 1500 AD (Goff and Nunn 2016). Similarly, on Futuna island (Wallis and Futuna), there is geological evidence for a palaeotsunami dated to around the mid-fifteenth century, with an associated oral history and settlement movement inland and uphill (Goff et al. 2011b).

A brief review of existing geological research in the SW Pacific indicates that palaeotsunami evidence has been found on Vanuatu, the Cook Islands, Wallis and Futuna, Samoa, American Samoa, Fiji, Tonga, Papua New Guinea, the Hawaiian Islands, the Austral Islands, Henderson Island, the Marquesas Islands and the Society Islands (Fig. 1) (summarised in Frohlich et al. 2009; Goff et al. 2011a; Williams et al. 2013). The growing body of interdisciplinary evidence for an event around the midfifteenth century means that region-specific archaeological proxies such as region-wide coastal village abandonment, oral traditions, anomalous coral sand/pumice layers and reworked sand dunes (Goff et al. 2008a, 2011a) can also act as analogues for earlier events such as that proposed for 2800 years BP in the early stages of the settlement of Western Polynesia (Kirch 2010).

The geological and archaeological findings indicative of palaeotsunamis within the wider Pacific region discussed above provide a fragmentary, but important record that is similar to the more comprehensive dataset developed in New Zealand (McFadgen 2007).

\section{Prehistoric Mass Burial Sites in the SW Pacific}

Numerous prehistoric burials (single and multiple) have been reported by archaeologists throughout the Pacific region. Here we review two recently reported sites that have contrasting characteristics and investigate the implications of these findings for other mass burials in less tectonically active areas. 


\section{Namu, Taumako, Solomon Islands}

The burial site at Namu on Taumako (Duff Islands) was studied between 1977 and 1978 but not fully reported for some 30 years (Leach and Davidson 2008). In their report, Leach and Davidson (2008) observed that some, if not all, of the coastal areas in the islands had been affected by high-energy marine inundations during the period of human occupation with on land marine deposits and reworking of cultural layers. Archaeological evidence for possible palaeotsunami inundation was present in several forms including Kilikili-surface scatters of coral gravels (n.b. in this case, Leach and Davidson (2008) interpret these scatters in a more conventional archaeological manner as evidence for past village sites), scattered human bones and more concentrated mounds of human remains (incl. surface scatters of fragmented human bones, shell money beads, pieces of Trochus arm rings and worked Nautilus shell) (Fig. 2).

The main Namu site, almost $100 \mathrm{~m}$ inland from the coast, consisted of a low mound about $7-8 \mathrm{~m}$ in diameter and $70 \mathrm{~cm}$ above the surrounding area. Associated material included a second, smaller burial mound and several scatters of human bones (Fig. 2d). The surface of the mound was comprised of scattered coral slabs and boulders,
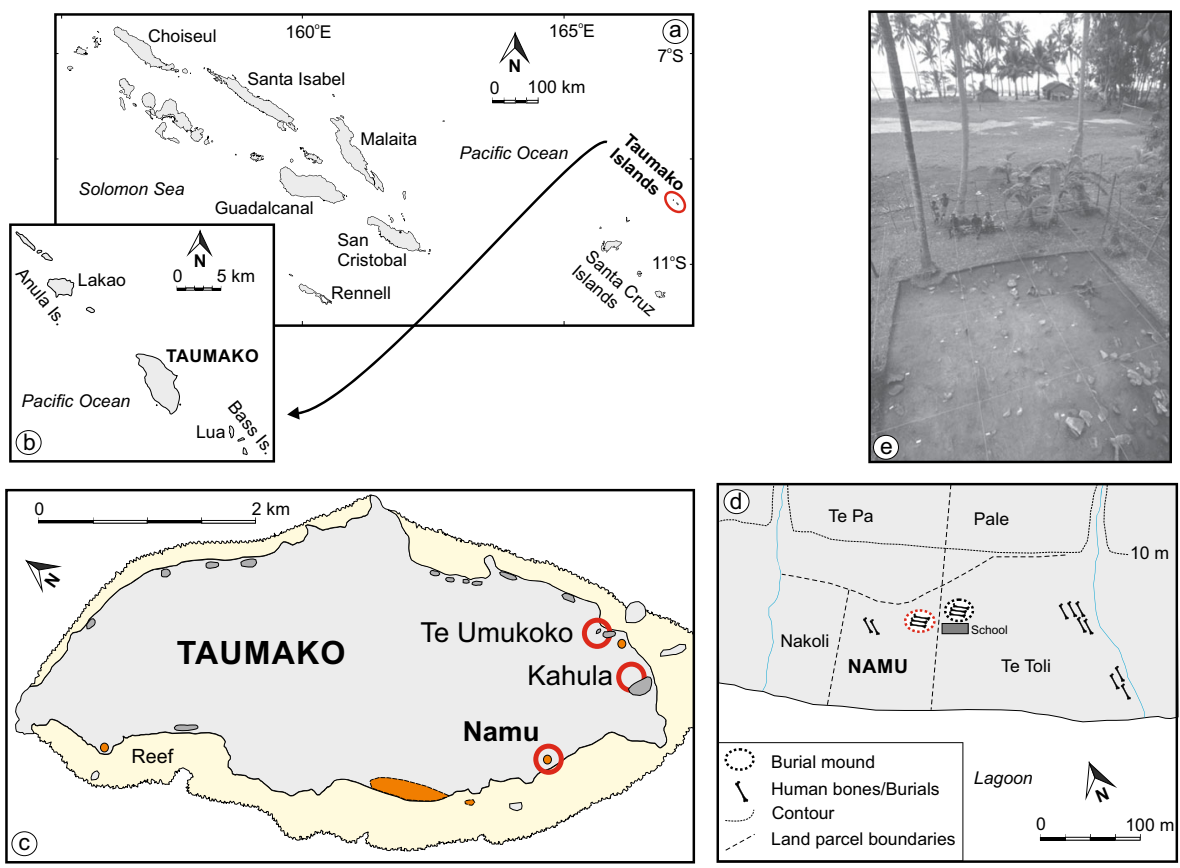

Fig. 2 Solomon Islands: a location of Taumako Islands in the island archipelago; b details of Taumako Islands (showing names of others mentioned in the text); $\mathbf{c}$ plan of Taumako Island (dark grey-shaded areas near the coast indicate possible past village sites, orange areas indicate occupation scatter and/or surface finds of human remains, open red circles mark key sites mentioned in the text) (modified after Leach and Davidson 2008); d sketch map of Namu and adjacent land parcels, showing the excavated mound (in red) and other surface evidence of burials (modified after Leach and Davidson 2008); e aerial view of Namu excavation looking south (numerous skeletal outlines visible). The lagoon and reef can be seen in the distance (Fig. 6.2. in Leach and Davidson 2008) 
fragments of human bone, some worked Nautilus shell, broken Trochus rings and shell money beads. Almost no midden was found at Namu, there was no food shell, and there were only a few bones of fish and animals (Leach and Davidson 2008).

A total of 201 individual burials was recognised although because of the comingling of bones a recent study has proposed up to 226 (Buckley and Tayles 2003). The burials themselves involved a simple process of placing the body on the surface of the ground and heaping a small amount of coral gravel over it. In other words, little or no digging was involved. There were patches of gravel and sand, some of which were 'clean' indicating that it had come from a water-washed area such as a beach, but equally there were some sediments with charcoal staining, suggesting that it had been sourced from living areas (Leach and Davidson 2008).

The bodies had been laid down stretched out on their back with their legs and arms straight down the body. They were oriented in one of two distinct directions in rows. Some form of bodily mutilation affected a large number of individual skeletons, often with hands and/or feet entirely missing. It was inferred that this probably occurred postburial due to exposure caused by the thin covering of sediments. With definite signs of rat gnawing, this disaggregation was most likely associated with post-mortem animal activity (incl. rats, pigs, dogs) (Leach and Davidson 2008). Numerous healed bone puncture wounds were noted, possibly caused by everyday accidents or fighting. These types of injuries reflect the general health of the population at the time.

Most of the adults, with some exceptions, died fairly young (males: average 26.3 years old; females: average 25.3 years old), some 3-6 years younger than normal (Houghton, in Leach and Davidson 2008). There seems to have been few if any indications of differential status between one age grade and another. Infants and children were sometimes buried with heavy ornaments which they could never have worn in life, while others worn only by men today were buried randomly with men, women or children. In contrast to these personal ornaments, only one adze seemed to be unequivocally associated with a burial, although other scattered ones may have been (Leach and Davidson 2008).

The findings from this burial site are unusual because there is a general sense of disorganisation. The authors acknowledged this dilemma and noted that the kind of burials discovered were so close together that "even if they were not actually buried at the same time, the interval between them must have been short enough for the living to know that the second person was close kin to the first and therefore should be buried very close to him or her" (Leach and Davidson 2008, p. 217). This statement seems at odds with two key findings. First, the burials appear disorganised; and second, they are shallow to the point of being almost totally exposed on the ground surface. Neither is characteristic of Polynesian mortuary practices.

The site dates to $1220-1745$ AD (six pooled dates with a minimum range of 12751655 AD) towards the end of the sequence of occupation on Taumako. A site duration range of 450 years was assigned since it was the mid-point between the two age ranges (380 and 525 years). Fourteen potential burial layers were identified, and while acknowledging that there was no way of knowing what the actual time gap between any one of these might be, anything from 1 day to one century, an average of about 32 years was inferred for each of these layers (Leach and Davidson 2008). Unfortunately, this inevitably leads the authors to focus solely on an ongoing use of the burial site throughout much of the later part of the Namu period (1000-1800 AD) and not to 
consider multiple hypotheses (Chamberlin 1890). In doing so, they focus on minor variations such as body orientation through time (over decades/centuries) which could just as easily reflect a rapid, single event mass burial.

The rationale for suggesting multi-decadal layers is questionable since a statistical review of the radiocarbon dates indicates no significant difference between them, and as such, they are equally consistent with a single event. This does not prove a single event, but it does not disprove one either. Assuming these dates do represent a single event, the weighted mean and standard error is $538 \pm 65$ years BP. This age range fits well with the proposal that it might relate to a single mass burial associated with the region-wide mid-fifteenth-century palaeotsunami discussed above.

While there was no traditional knowledge in the form of oral history concerning the site, the name Namu can be translated from Polynesian to mean 'bad smell' (Leach and Davidson 2008). Polynesian place names often represent an archive of intergenerational experiences of the environment (King et al. 2007), and it is plausible therefore that the name Namu may represent the last remaining cultural evidence of a hastily dug mass burial site. Once the possibility of the Namu site being a mass burial is considered, several inconsistencies reported by the authors appear to be more logical:

- The method of burial was unusual in that bodies were placed on the ground as opposed to in graves, with coral gravel heaped over and around the body (Leach and Davidson 2008). This is consistent with rapid burials carried out in an area of thin substrate underlain by coral, where there is a need to ensure that bodies are contained within a specific area.

- The age of adults buried is younger than average for the Namu people (Leach and Davidson 2008). It seems reasonable to suggest that this represents the general age distribution of the population at the time of death. This catastrophic event affected all age groups, not just the elderly.

- Kilikili were observed in many coastal locations (Leach and Davidson 2008). While their use as evidence for past village sites is undoubtedly a valid archaeological interpretation, similar sedimentological evidence has been used consistently as a proxy for palaeotsunami inundation (Table 2, point 20). A tsunami deposit tends to fine inland. There are large coral clasts stranded on the reef flat immediately offshore from both Taumako and Lakao island to the north (Fig. 2b); therefore, gravel clasts (kilikili) at or near the coast and sand farther inland are consistent with a palaeotsunami interpretation. For example, at Te Ana Tavatava on the north side of Lakao, a sand/gravel unit some $50 \mathrm{~m}$ inland dated to 1299-1470 AD has reworked underlying sediments. Leach and Davidson (2008) do not discuss this further but dating is consistent with that of a mid-fifteenth-century palaeotsunami.

The case for Namu being a mass burial site related to palaeotsunami inundation is further supported by Taumako's tectonic context. It sits between two tectonically active trenches, San Cristobel some $250 \mathrm{~km}$ west and Cape Johnson around $180 \mathrm{~km}$ east (broadly associated with the Solomon Trench at the interface between the Australian and Pacific Plates - Fig. 1). Most recently, the former was responsible for the unusually large tsunami generated by a Mw7.1 earthquake in 2010 (Newman et al. 2011), and the latter is noted as the source for numerous oral histories concerning large waves affecting many islands in the prehistory of the region (Nunn et al. 2006). 
Leach and Davidson (2008) noted that there appeared to be evidence for significant changes in coastal geology and geomorphology on both Taumako and Lakao. On Lakao, there is evidence for tectonic uplift at the beginning of the Tavatava Period (1000 to 400 BC) with a stranded inland wave cut notch fronted by 'clean' white sand. This uplift probably occurred immediately prior to the first arrival of people around $900 \mathrm{BC}$ (thus making temporary occupation of this notch area possible). Intriguingly, this date is contemporaneous with a region-wide palaeotsunami around 2800 years BP (Goff et al. 2012b). On the other hand, on Taumako, there were extensive lowland swampy areas formed around the same time indicating a change in the drainage system following uplift (and possibly altered drainage following sand deposition during tsunami inundation; Table 2: point 26).

The case for a mid-fifteenth-century palaeotsunami in the region is strong. Geological evidence exists throughout the SW Pacific, currently extending as far west as Wallis and Futuna (1700 km E of Taumako) or possibly Vanuatu (700 km S) (Goff et al. 2011a, b). There is archaeological evidence on Wallis and Futuna for movement of settlements inland and uphill and for hillfort construction on the Solomon Islands around 1500 AD (Goff and Nunn 2016). Contemporaneous anthropological evidence for rapid social changes are found on Pukapuka (3000 km E), Ontong Java (1000 km NW) and Ulawa Island (400 km W) in the Solomon Islands, the Gilbert Islands (1700 km NE), the Lau Group (Fiji) (1500 km SE) and Wallis and Futuna (1700 km E) (Sahlins 1957; Goodenough 1955; Hogbin 1931). Oral histories are also reported from the Solomon Islands, Vanuatu, Wallis and Futuna (Goff et al. 2011a, b; Nunn et al. 2006).

When viewed as a whole, there are geological, geomorphological, archaeological and anthropological characteristics indicative of a mid-fifteenth-century palaeotsunami (Table 4). Even as a stand-alone proxy, the Namu site has many of the characteristics of a mass burial indicative of the effects of catastrophic palaeotsunami inundation on prehistoric coastal communities (Table 4). When considered in conjunction with the additional evidence discussed above, a more reasonable question might be, why is this not a mass burial site related to the SW Pacific region-wide mid-fifteenth-century palaeotsunami?

\section{Teouma, Vanuatu}

Teouma is on the south coast of Efate, Vanuatu, a tectonically active country adjacent to the New Hebrides trench (Figs. 1 and 3). The site is located about $800 \mathrm{~m}$ inland on the edge of an uplifted beach/reef about 8 masl on the NE side of Teouma Bay (Fig. 3) (Bedford et al. 2006). This cemetery/mass burial site was uncovered by quarrying in 2003 and was first reported in detail by Bedford et al. (2006). Burials were in shallow graves dug into the tephra in gaps in the uplifted beach/reef along a NE-SW trending zone, 10-15 m wide, adjacent and parallel to the former beach (Bedford et al. 2009). A total of 68 burial features were identified representing up to 91 individuals of which about $80 \%$ were adults (both sexes) and the remainder, infants (newborn/pre-term) (Bedford et al. 2006, 2009; Kinaston et al. 2009; Valentin et al. 2011).

From a Pacific archaeology perspective, this site is of exceptional importance since it contains the earliest and most extensive collection of burials thus far associated with early human settlement (Lapita) of the Pacific Islands, and dates to around 2800- 
Table 4 Summary of site-specific palaeotsunami-related mass burial characteristics and other proxy evidence (see text for details)

Characteristic

Namu, Teouma,

Solomon Is. Vanuatu

1. Rapid burial usually with little/no consideration of cultural sensitivities - however may involve later excarnation activity

2. Often associated with some individual burials (either early attempts to follow ritual, or burial of highly esteemed people)

3. Burial in shallow trenches or pits (often $<1.0 \mathrm{~m}$ deep) or under mounds of stones or debris

4. Use of existing burial sites and/or closest to largest number of bodies - tend to be found at or near the coast

5. Body arrangement either in a 'rack system' with bodies laid facing one direction (or in alternating directions for each layer) or in an unstructured manner

6. Comingling of bodies and, subsequently, skeletal remains can occur

7. Sometimes divided into sections (e.g. separate area for children)

8. Animals may feed on corpses causing variable amounts of dismemberment of the bodies (either pre- or post-inhumation). Often fragmentary skeletons buried together

9. Graves can sometimes include animals/fish (killed in event?)

10. Since death is usually by asphyxiation, drowning, impact injuries and wound infections, skeletal remains often show no visible signs of tsunami trauma

11. At prehistoric sites, radiocarbon (or other) dating invariably indicates burials occurred during a short period of intensive site use as opposed to a specific date. Individual burials before or after mass burial will reflect use over longer time period

12. General age distribution of skeletons most likely reflects population at the time

13. Warfare/defence injuries may be noted on some skeletons, reflecting the nature of the general population at the time

14. Can be associated with geological evidence for the palaeotsunami at the site - usually dug into or mixed with it

15. Local knowledge about potential prehistoric mass burial sites may be preserved in oral traditions, or this information may be lost (either too long ago, or possibly due to significant loss of indigenous knowledge caused by large magnitude events). n.b. The absence of oral traditions is not evidence for the absence of an event

16. Other archaeological evidence (Tables 2 and 3)

17. Contextual evidence (Table 2)

\begin{tabular}{|c|c|}
\hline$\sqrt{ }$ & $\sqrt{ }$ \\
\hline$?$ & $?$ \\
\hline$\sqrt{ }$ & $\sqrt{ }$ \\
\hline$\sqrt{ }$ & $\sqrt{ }$ \\
\hline$\sqrt{ }$ & $\sqrt{ }$ \\
\hline$\sqrt{ }$ & $\sqrt{ }$ \\
\hline$\sqrt{ }$ & $\mathrm{X}$ \\
\hline$\sqrt{ }$ & $\sqrt{ }$ \\
\hline$?$ & $\mathrm{x}$ \\
\hline$\sqrt{ }$ & $\sqrt{ }$ \\
\hline$\sqrt{ }$ & $\sqrt{ }$ \\
\hline$\sqrt{ }$ & $\sqrt{ }$ \\
\hline$\sqrt{ }$ & $\mathrm{x}$ \\
\hline$\sqrt{ }$ & $?$ \\
\hline$?$ & $\sqrt{ }$ \\
\hline$\sqrt{ }$ & $\sqrt{ }$ \\
\hline$\sqrt{ }$ & $\sqrt{ }$ \\
\hline
\end{tabular}

3000 years BP (Bedford et al. 2009; Petchey et al. 2014). An interpretation of all of the radiocarbon samples places site abandonment no later than 2500 years BP (Bedford et al. 2009). A Bayesian evaluation suggests that the burial ground was possibly in use as early as 3110-2930 years BP, probably in regular use by about 2940-2880 years BP, with last interments around 2770-2710 years BP. However, it was noted that what may be considered to be phases of occupation realistically overlap within two standard deviations because of the flatness of the calibration curve during this time period (Bedford et al. 2006). While the burial ground may have been in use for a 150-240-year period, it may equally represent burials related to a single event, or with the majority of burials occurring at one time but with individual usage at other times. 


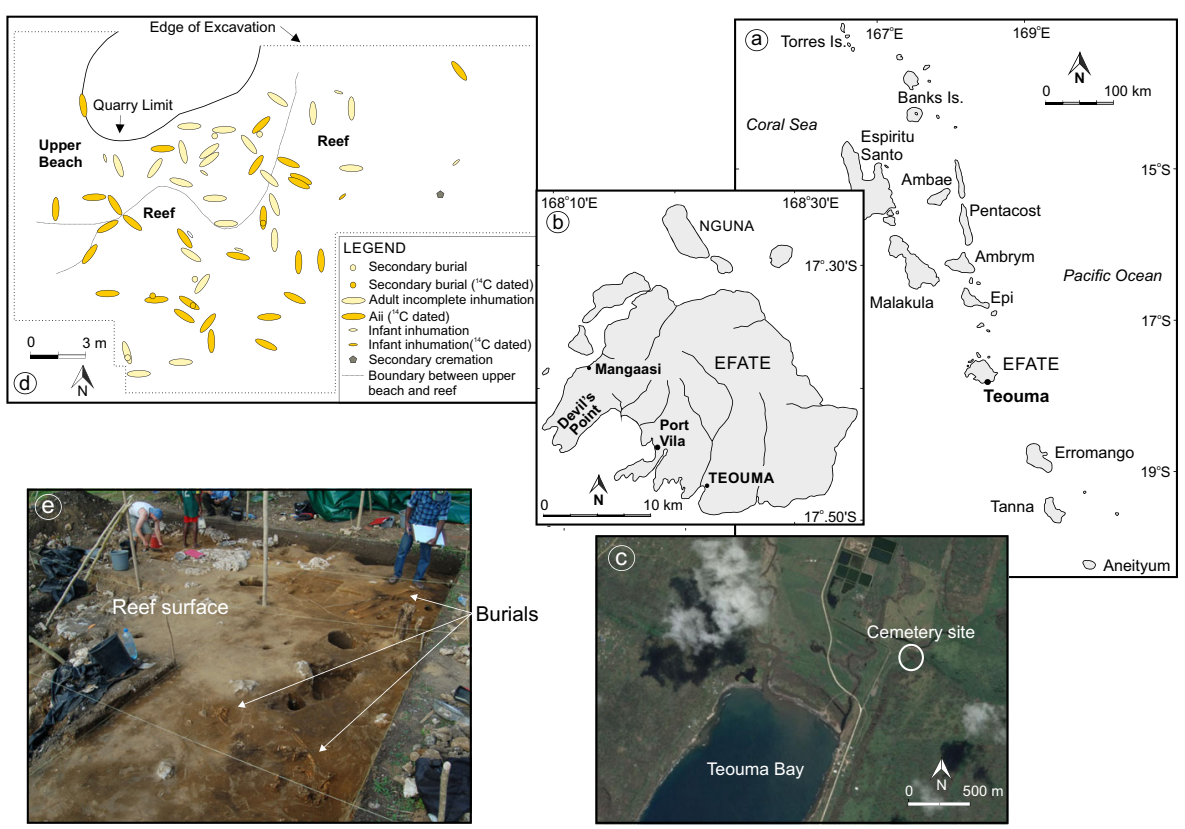

Fig. 3 Vanuatu: a location of Efate and Teouma in the island archipelago; b Teouma in southern Efate; c Google Earth image of cemetery location; d plan of the Teouma cemetery showing location of dated burials (simplified after Petchey et al. 2014); e excavation at the Teouma cemetery (photo: Max Plank Institute for the Science of Human History 2017)

Overall, there is a general agreement that the cemetery was probably used for only a short period of time based upon the redeposition of human remains, similarity of mortuary practice across the site and limited inter-cutting of burials (Bedford et al. 2009; Valentin et al. 2010). Valentin et al. (2010) clarify this further by inferring that the Teouma burials were not associated with a single event as indicated by the breakage and scattering of pottery due to successive mortuary activities at the site. It is also suggested that people had a level of awareness of the location of particular burials, perhaps through grave markers (pots and/or large boulders, including flat, rectangular coral slabs, were placed over the top of several graves), similar to those used in the early colonisation phase in New Zealand at the Wairau Bar, New Zealand (Bedford et al. 2009; Valentin et al. 2010). However, the cemetery site is unusual since later occupational debris (e.g. middens) dated to around 2800-2500 years BP (early Erueti Phase) overlies it (Bedford et al. 2006). In Polynesian culture, this represents an unusual disrespect for the dead and most likely indicates that knowledge of this part of the site as a burial area had already been forgotten (Bedford et al. 2006), possibly indicating a loss of cultural memory.

At Teouma, there appear to have been other similar findings to the New Zealand analogue, with two apparent phases of burial. Primary interments consisted of a wide array of burial positions with clear indications of body manipulation at an early stage of body decomposition (Bedford et al. 2009; Valentin et al. 2010). Such manipulation may well have been a pragmatic response to fitting bodies within the available topography with one partially articulated skeleton found 'buried' on the surface of the reef(Valentin et al. 2010). 
In all burials, the skulls and sometimes other bones appear to have been removed some time after internment (Bedford et al. 2006; Valentin et al. 2010, 2011). Subsequent additions/re-burials of rare ornaments, shells and bone collections occurred, and pots containing human remains were also recorded (Bedford and Spriggs 2007). One proposal was that the bone collections and pots containing human remains might have been brought from an entirely different location to the cemetery (Valentin et al. 2010).

It is important to put this site in its wider environmental context. Bedford et al. (2006, 2009) noted that tectonic activity probably created a progressively prograding shoreline and that there was a continual realignment of the settlement to maintain it in the preferred location for habitation, adjacent and parallel to the contemporary beach. It is inferred that continued uplift led to the ultimate abandonment of the settlement with easy access to the sea becoming increasingly problematic (Bedford et al. 2006, 2009). The site is now $800 \mathrm{~m}$ inland, but even today the sea is easily accessible and the proposed cause for abandonment seems unlikely. Perhaps of more significance to the interpretation of this site is the regional tectonic activity and recognition of a major region-wide palaeotsunami that occurred some 2800-3000 years BP (the 2800-year BP event) during the time of initial Polynesian (Lapita) settlement (Goff et al. 2012b).

With this in mind, is there any convincing argument that could be developed to infer that the Teouma burials might be tsunami-related? There are two sites on Efate that preserve evidence for the 2800-year BP event, $10 \mathrm{~km} \mathrm{WNW}$ at Devil's Point and $25 \mathrm{~km}$ NW at Mangaasi (Goff et al. 2011a), which makes this a plausible argument worth exploring. The observation that later occupation debris (early Erueti Phase $\sim 2800$ 2500 years BP) overlies the burials mirrors findings elsewhere in the SW Pacific. This was either a highly unusual sign of disrespect, a loss of cultural memory (noted in the wake of numerous past tsunamis, e.g. PNG: McSaveney et al. 2000) or possibly reworking of the debris by a tsunami (McFadgen and Goff 2007).

Given the limited areal extent on the uplifted beach/reef to accommodate a settlement, the use of much of the site for a burial ground is unexpected. If viewed from the perspective of a mass burial related to deaths from a tsunami, then this pragmatism is understandable - burials occur close to the highest number of victims. There appears to be little in the way of ritual burial and it is plausible that what is viewed as body manipulation could in part be related to soft tissue injuries incurred by the tsunami, the latter allowing burial within the close confines of the reef cavities. While it is important to caution against selectively picking through the available data, there are notable commonalities such as the reworking of anthropogenic material (scattered potsherds/ bones) and the recognition that the bone collections and pots containing human remains might have been brought from an entirely different location to the cemetery (Valentin et al. 2010), representing a potential catchment area for skeletal remains related to the event. The discovery of one partially articulated skeleton buried at the surface of the uplifted reef suggests that this site was rapidly filled in as opposed to representing a long-term burial site. The use of possible tsunami-related sediments to cover the burials cannot be overlooked, with large coral boulders and/or rectangular coral slabs placed over the top of some graves. Large reworked coral clasts commonly form part of a tsunami deposit in such a reefal/beach environment (e.g. Goff et al. 2011a, b). Abandonment of the area at this time, invariably by movement inland and uphill (e.g. McFadgen 2007), with subsequent reoccupation in the early Erueti Phase could explain the presence of middens overlying part of the site and the loss of cultural memory of it. 
A summary of site-specific palaeotsunami-related mass burial/grave characteristics and other proxy evidence from this site is listed in Table 4.

\section{An Alternative Hypothesis for the Interpretation of Mass Burials in NW Europe?}

\section{Introduction}

Two Pacific region examples of potential mass burial sites related to deaths caused by palaeotsunami inundation have been discussed above. Both have distinct similarities and differences. There are marked variations in environmental conditions, mortuary practices and numbers of deceased. However, as coastal sites contemporaneous with known palaeotsunamis in the region, the possibility that they relate to mass deaths associated with a catastrophic tectonic-related event cannot be ignored.

There are undoubtedly numerous mass burial sites that are contemporaneous with similar catastrophic tectonic-related events in the Northern Hemisphere. Indeed, a brief search of mass burial sites in the Mediterranean produces several candidates worthy of further study, two of which from Greece are briefly described below.

Archaeologists have interpreted three general categories of mass burial in ancient Greece, those related to deaths from warfare, hasty burials for the victims of an epidemic or famine and those of prisoners of war or convicts (Little and Papadopoulos 1998). Triantaphyllou and Bessios (2005), however, report on a different possible category. They discuss a mass burial of 115 comingled individuals at Pydna, Macedonia, NE Greece (Fig. 1). The burial took place in the second half of the fourth century BC with bodies thrown, without any sign of formal mortuary treatment, into a 4-m deep rock-cut shaft. The perceived low status of the population represented here (low average age at death, generally poor health, skeletal manifestations of heavy physical stress - some were in iron shackles) caused them to infer that this might be evidence for a mass burial related to ancient slavery. However, there were at least 42 adults, 16 sub-adults, children and juveniles of both sexes - a balanced demographic representation of both sexes. While they may have been low status, the shackled skeletons (slaves) may simply reflect their relative distribution within the population at the time.

A point overlooked by the researchers is that Pydna is located at the head of the Thermaic Gulf, a NW-SE-oriented embayment in the NW corner of the Aegean Sea and adjacent to the tectonically active North Aegean Trough. The earliest historically documented tsunamigenic earthquake in this region occurred in $330 \mathrm{BC}$ around Lemnos Island, a mere $220 \mathrm{~km}$ SE (Altinok et al. 2009, 2011; Soloviev et al. 2000). This large magnitude earthquake is thought to have resulted in the disappearance of Chrysi Island and the Moschylos volcano (Soloviev et al. 2000) with tsunami deposits reported from the Turkish coast some $180 \mathrm{~km} \mathrm{NE}$ (Altinok et al. 2013). It is noteworthy that in such a tectonically active region, there has been no consideration of the possibility that these mass burials may be related to this contemporaneous event.

It is here in Greece that a single reference is made to the consideration of a possible linkage between a tsunami and a mass burial. Little and Papadopoulos (1998) summarised the 1970s work of Kritzas at Argos in the eastern part of the Peloponnese 
Peninsula, some $180 \mathrm{~km} \mathrm{NW}$ of Crete (Fig. 1). Here, a well containing 20 human (incl. ten male, six female, three infants) and numerous animal skeletons (horse, cow, pig, sheep, goat, dog) was dated to the Late Helladic (LH IIIB) period around 1250-1300 BC. In attempting to explain the reason for this mass burial, Kritzas (1976-1978, in Little and Papadopoulos 1998) considered the presence of the animals to be unusual and tentatively concluded that these were all flood victims. While not directly suggesting a tsunami as an explanation for the burials, he noted in the writings of Pausanias (a Greek traveller and geographer of the second century AD) a section (2.22.4) dealing with the Sanctuary of Poseidon, "for they say that Poseidon inundated the greater part of the country because Inachus and his assessors decided that the land belonged to Hera and not to him. Now it was Hera who induced Poseidon to send the sea back, but the Argives made a sanctuary to Poseidon Prosclystius (flooder) at the spot where the tide ebbed" (Jones 1918). Kritzas raised the possibility that this story may be referring to the flooding of the plain of Argos by the tsunami associated with the Thera (Santorini) eruption around $1350 \mathrm{BC}$ (Bruins and van der Plicht 2014; Little and Papadopoulos 1998).

Pydna and Argos are two of many mass burial sites reported from tectonically active areas of NW Europe (and the Northern Hemisphere). It seems reasonable to suggest that further work needs to be done to investigate other possible tsunami-mass burial linkages not only at these two sites, but also at other locations where such an explanation may be valid. There is a danger however in focussing solely on tectonically active areas.

\section{Mass Burials in Relatively Tectonically Inactive Areas}

Perhaps the most well-known tsunamigenic slope failure in the Northern Hemisphere is the 8150-year BP Storegga slide, the only known prehistoric submarine slope failure with extensive geological evidence for a catastrophic region-wide tsunami (Bondevik et al. 2005a; Smith et al. 2004). The Storegga slide was not generated by tectonic activity and occurred on the edge of the continental shelf offshore of western Norway (Fig. 1). It has an estimated volume of $2400-3200 \mathrm{~km}^{3}$ with a slide area some $20 \%$ larger than Scotland (Løvholt et al. 2017). Geological evidence can be traced from Norway to Greenland, western Scotland, NE England and Denmark (e.g. Bondevik et al. 2005a; Long et al. 2016; Smith et al. 2004). The effects of this tsunami on the Mesolithic forager populations of western and eastern Scotland were immediate and long-lasting (Waddington and Wicks 2017; Wicks and Mithen 2014).

There is little doubt that the Storegga tsunami was catastrophic both for the coastal landscape and population densities (Waddington and Wicks 2017). This event occurred at a time when sea levels were about 10-15 m lower than present, although isostatic adjustments of landmasses in response to past ice cover cause some variability in this figure (Bondevik et al. 2005a). The Shetland Islands in northern Scotland (Figs. 1 and 4) had runup heights of over $20 \mathrm{~m}$ above the sea level at the time.

There is also evidence on Shetland for a more recent tsunami that affected the area around 5500 years BP (Bondevik et al. 2003, 2005b; Dawson et al. 2006; Ishizawa et al. 2016). It has similar sedimentary characteristics to the 8150 -year BP Storegga tsunami and probably had a runup of more than $10 \mathrm{~m}$ (Bondevik et al. 2005b). The 5500-year BP Garth tsunami (hereafter called the 5500 BP event) was initially found in Sullum Voe and then at two lake basins (Garth and Lake of Benston) on the eastern 
coast of Mainland (Fig. 4). It may also be present in some Norwegian coastal lakes (Bondevik et al. 1997). This event could represent a later (and smaller) submarine slope failure from the Storegga area or may be related to the Afen slide about $120 \mathrm{~km} \mathrm{NW}$ of Shetland (Fig. 1) (Bondevik et al. 2005b; Haflidason et al. 2005; Long et al. 2003). The Afen slide occurred sometime after 5800 years BP, but its volume $\left(0.4 \mathrm{~km}^{3}\right)$ was probably too small to generate a tsunami of any size (Bondevik et al. 2005b). However, more recent work has found that comparatively small submarine slope failures (i.e. < $1 \mathrm{~km}^{3}$ ) can produce locally large tsunamis (Frohlich et al. 2009). No evidence has so far been reported for this event on either mainland Scotland or Orkney. However, when searching for evidence for the larger 8150-year BP Storegga tsunami, Dawson and Smith (2000) noted the sheltering effect of the Orkney and Shetland Islands located immediately in the path of an incoming tsunami from the continental slope.

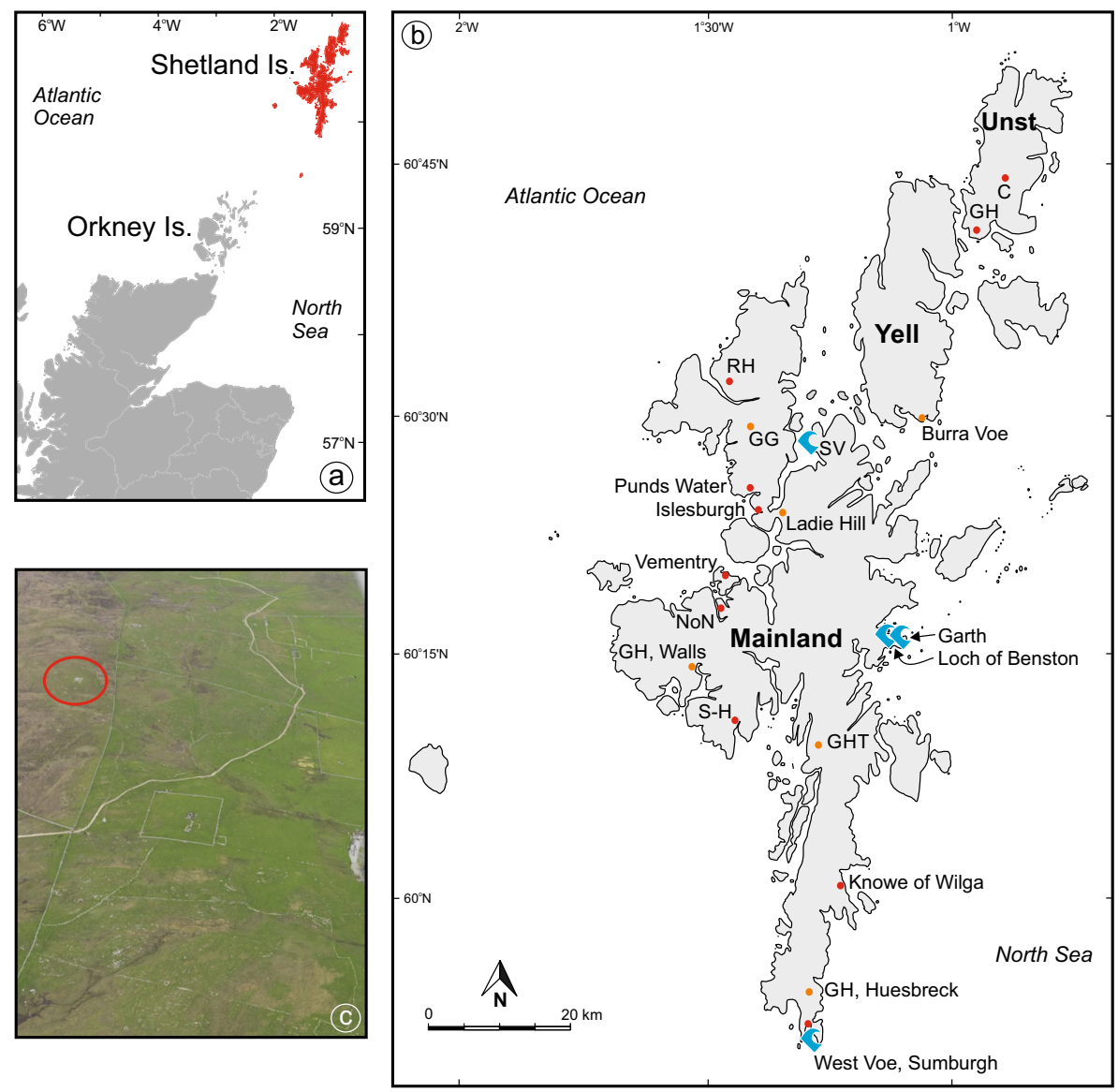

Fig. 4 Shetland Islands: a location of Shetland Islands north of Scotland; $\mathbf{b}$ detail of Shetland Islands (excl. Fair Isle) showing place names mentioned in the text $(\mathrm{C}=$ Caldback; $\mathrm{GG}=$ Gulga, Glass, Northmavine; GH = Gallow Hill; GH, Huesbreck = Gallow Hill Huesbreck; GHT = Gallow Hill Tingwall; GH, Walls = Gallow Hill, Walls; RH = Ronas Hill; S-H = Swart-Houll; SV = Sullum Voe); c Gallow Hill, Unst: Neolithic chambered cairn (marked by red oval)—oblique aerial view looking east (photo: RCAHMS 2017a). Refer to Fig. 5 for symbol legend 
This suggests that geological evidence for the $5500 \mathrm{BP}$ event may exist on the Orkney Islands, although nothing has been reported to date (Fig. 5).

This begs the question: Is there any evidence in the archaeology of Orkney or Shetland for these events?

\section{Mass Burials on Orkney}

Archaeological literature for Orkney reveals the onset of a unique period of Neolithic prehistory marked by the construction of numerous chambered cairns (CC) around 5000-5500 years BP (Prendergast 2016). Davidson and Henshall (1989) describe 59 Orkney-Cromarty type CC passage tombs dated to the Middle/Late Neolithic. These

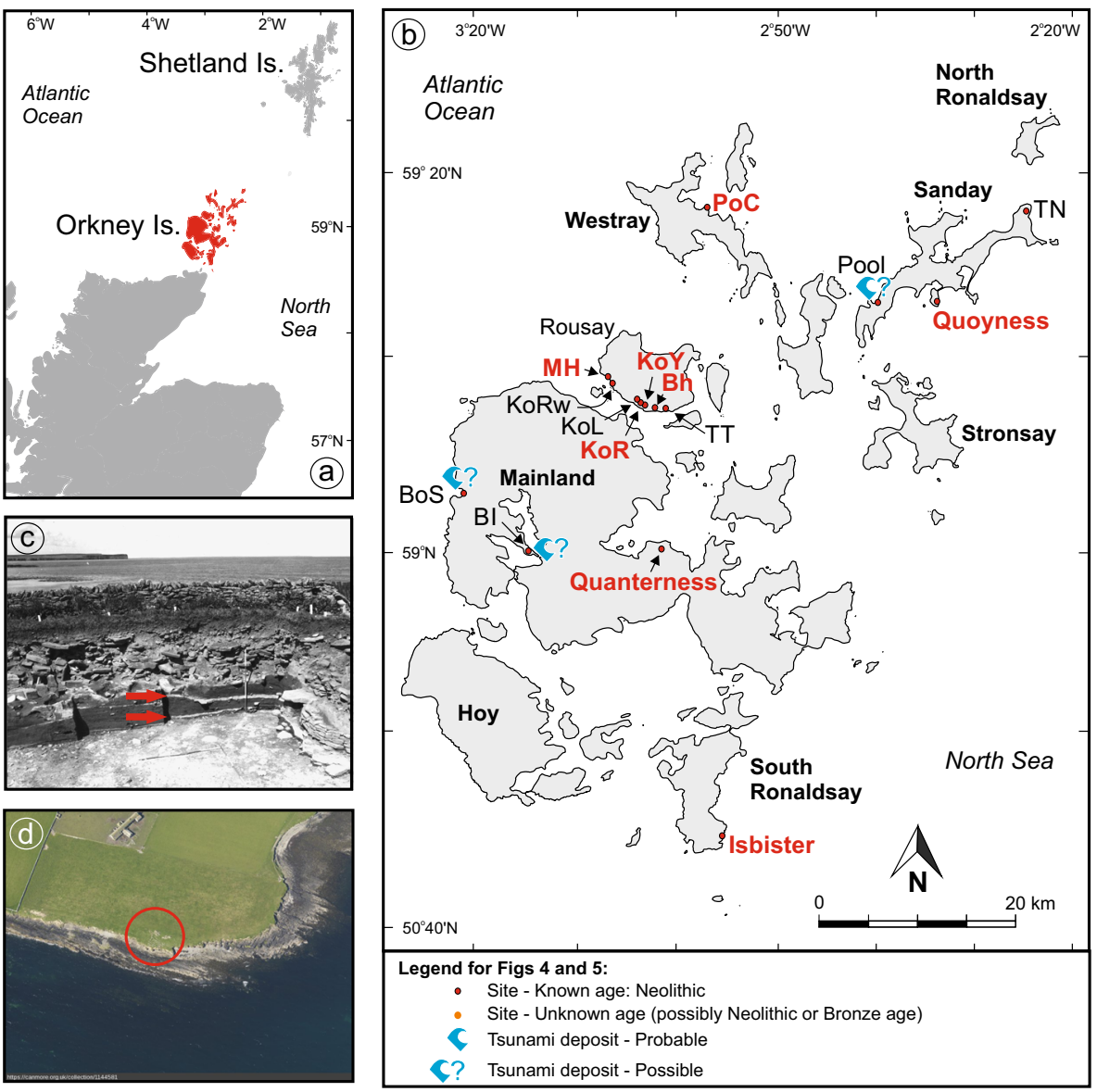

Fig. 5 Orkney Islands: a location of Orkney Islands north of Scotland; b details of Orkney Islands showing place names mentioned in the text $(\mathrm{Bh}=$ Blackhammer, $\mathrm{BI}=$ Brodgar Isthmus, $\mathrm{BoS}=$ Bay of Skaill, $\mathrm{KoL}=$ Knowe of Lairo, KoR = Knowe of Ramsey, KoRw = Knowe of Rowiegaar, KoY = Knowe of Yarso, $\mathrm{MH}=$ Midhowe, PoC $=$ Point of Cott, $\mathrm{TN}=$ Tofts Ness, $\mathrm{TT}=$ Taversoe Tuick), sites in bold red type are listed in Tables 5 and 6; c Neolithic site at Pool, Sanday: view of excavated section from the east. The lower (darker) part of the section represents the Neolithic deposits - two sand horizons are marked (after MacSween et al. 2015); d oblique aerial view of Point of Cott chambered cairn (shown within red circle) taken from ENE (RCAHMS 2017b) 
are mostly round cairns with a centrally placed chamber, characterised by a division into stalls separated by upright slabs of stone and sometimes double-tiered. However, there are also at least 12 other similar cairns called the Maes-Howe group. These have rectangular chambers, low entrances, more symmetrically placed side cells and long narrow access passages (Fig. 5; Table 5) (Henshall 1963, 1972).

Chronologically, a recent reassessment of radiocarbon dates related to numerous $\mathrm{CCs}$ on the Orkney Islands infers that $\mathrm{O}-\mathrm{C}$ types form a consistent group centring around 5500 years BP $(3500 \mathrm{BC})$ with a second phase $(\mathrm{M}-\mathrm{H})$ closer to 5000 years BP (3000 BC) (Schulting et al. 2010). This is an important distinction since to some extent it has bearing upon whether such tombs may have been related to a catastrophic event(s). In reporting the findings of this apparent age offset, Schulting et al. (2010) recognise that the available radiocarbon dating evidence for Orkney's CCs and Neolithic pottery does not accurately resolve differences between them largely because of a late fourth millennium calibration plateau. In other words, statistically, the full calibrated ranges of the radiocarbon dates overlap for both types of CCs to around 52005500 years BP (Table 5). While there may be a distinct chronological (as opposed to architectural/pottery) difference between $\mathrm{O}-\mathrm{C}$ and $\mathrm{M}-\mathrm{H}$ types, this does not necessarily negate the possibility that the bulk of the mass burials relate to a single event, especially since there may have been a movement of human bone assemblages between different CCs (e.g. Chesterman 1979). This may seem an unusual and moderately unfounded statement, but much of the debate surrounding the age and usage of CCs has built up around increasingly entrenched narratives invariably based around poorly recorded early sites with a few rare exceptions from recent work.

In the examples we have summarised, burials range in number from two at the badly disturbed site of Blackhammer, to potentially as many as 341 at Isbister (Table 5). These burials are almost all on high ground near the coast with the exception of Quoyness that appears to have been constructed close to a supply of building stone. In most cases, the CCs do not appear to represent a single mass burial event, but rather either start with a few individual burials or these continue after a mass burial, sometimes for millennia (Isbister). Alternatively, as hypothesised for the seven CCs on the south coast of Rousay, these contemporaneous or near-contemporaneous cairns may represent individual parts of a larger cemetery (Lawrence 2012; Prendergast 2016; Reilly 2003).

Why were so many CCs apparently constructed around the same time, and where did all the bodies come from? There have been several burial models proposed that partially address this question (Lawrence 2012). First, that they represent the bodies of a population buried over a short period of time. Second, they are a selection of highstatus individuals buried over a long period. Third, they are a selection of the unwanted dead buried over a long period of time (Barber 1988). Fourth, the tombs had an interment use for only a very short period (Whittle et al. 2007).

Based upon the equivocal nature of the existing radiocarbon dating coupled with some notable differences in burial practice, it would seem reasonable to propose that Orkney's CCs do generally represent tombs that had an interment use for a very short period, albeit with the occasional anomalous later burial. The common presence of contemporaneous comingled and disarticulated layers of bones suggests that these bodies represent a significant portion of an entire population buried over a short period. In brief, the purpose of the CCs could be viewed as having a mass interment use for a 


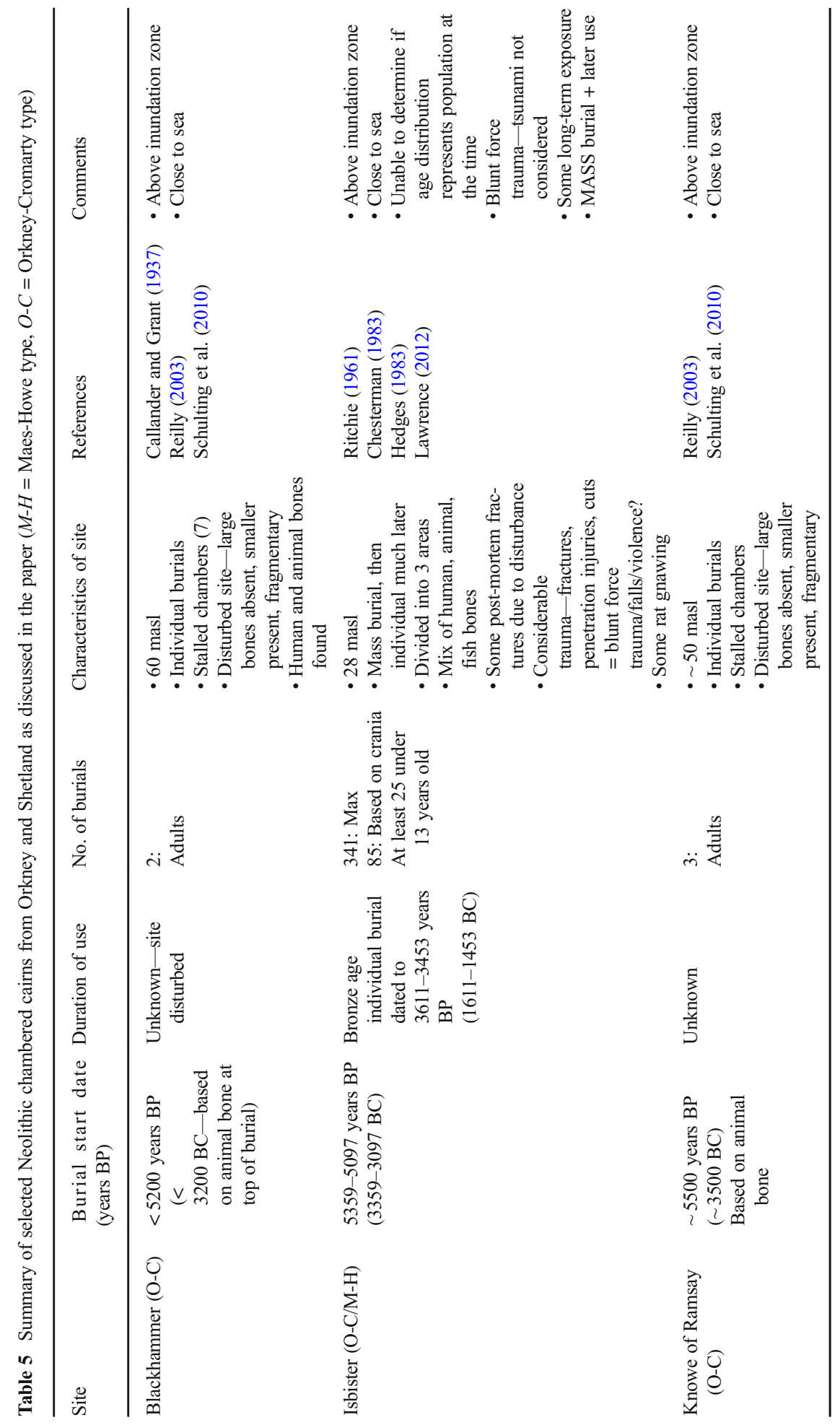




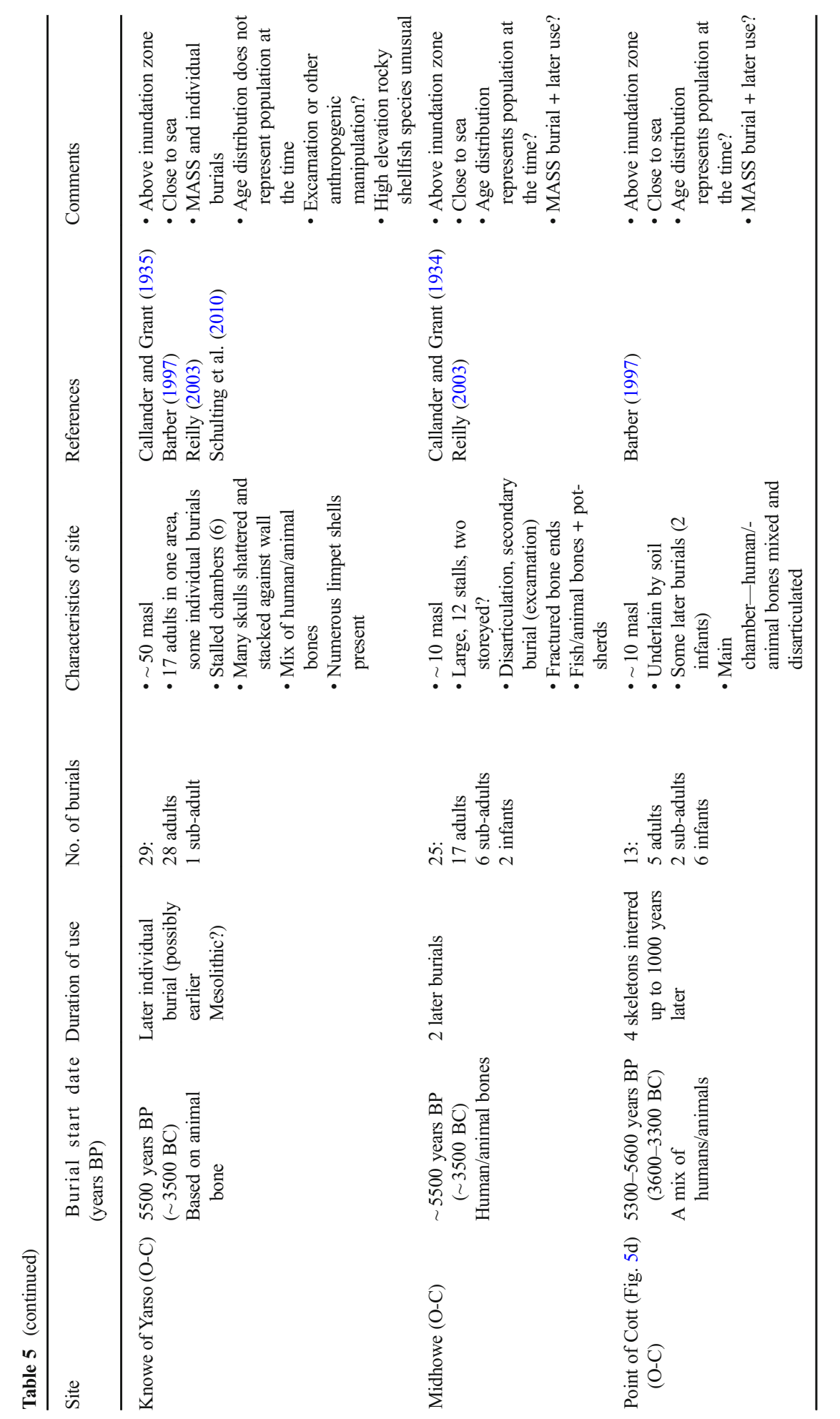




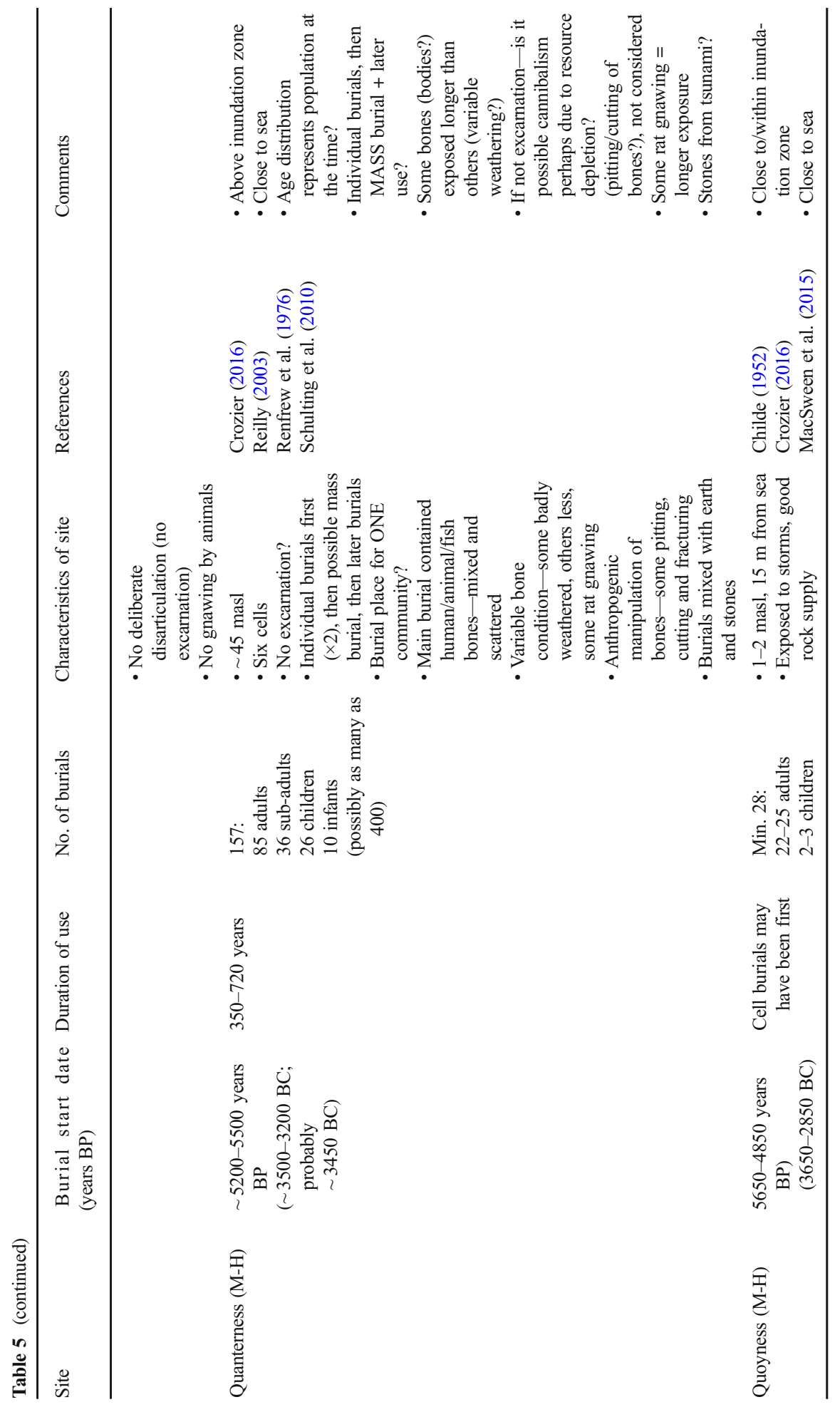




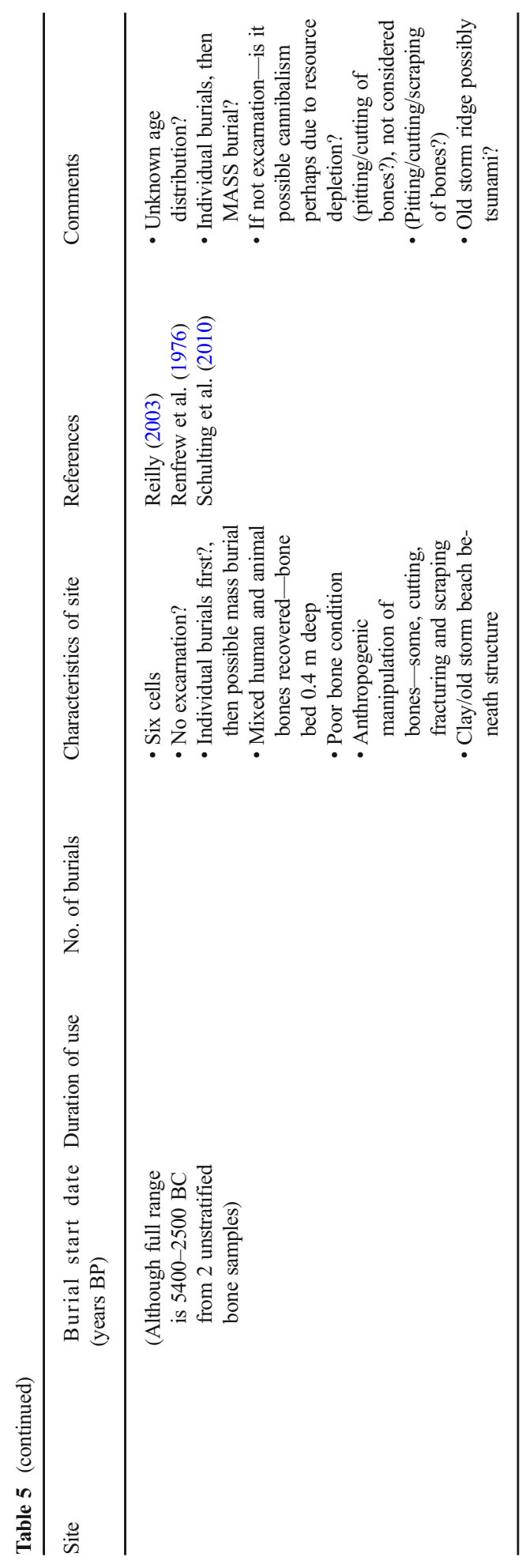


short period with some high-status individuals buried separately to the mass burial in a manner similar to that described by Minami et al. (2012) for the 1293 KJT. However, while this explanation may fit with one interpretation of the data, there are significant differences between the Orkney CCs and general characteristics we have defined for mass burials/graves related to deaths caused by palaeotsunamis (Table 6).

Rapid burial has largely been inferred from the nature of the bone beds reported, and proximity to the sea in Orkney is almost inevitable for any tomb. While the representative age distributions vary considerably, this is more likely due to past site disturbance and poor preservation. In reality, the possibility that such Neolithic tombs might relate to a single (or more?) catastrophic natural event such as a major storm or a tsunami has never been fully considered before, and as such, much of the available data has not been collected with this in mind. The time it took to erect these tombs (or a temporary enclosing structure) also has some bearing upon their relation to a catastrophic event. The favourable characteristics of the local flagstone as a building material and its abundant exposure at the coast suggest that tomb construction could have been rapid. While it is generally suggested that elevation and visibility are one of several cultural responses inherent in the tradition of tomb building (Whittle et al. 2007), in the face of a devastating event, it is more likely that the need for rapid construction was the driving force.

If such an event occurred, and the 5500-year BP Garth tsunami reported from Shetland suggests that it could have, then one could expect a high death toll, rapid burials, resource depletion and settlement abandonment (temporary or permanently). Rapid burial would mostly take place with little or no ritual, skeletons would be in a variety of conditions from variable exposure times, animals and marine life would also have perished, and while some excarnation and/or anthropogenic manipulation of bones undoubtedly occurred, there is also the possibility that some cannibalism might have taken place (e.g. Cole 2017; Villa et al. 1986). Nothing in the collated data (Tables 5 and 6) challenges these suggestions, but as with all such narratives, it only partially supports them.

In addition to the Neolithic tombs of Orkney, there are other lines of evidence that can be used to infer the 5500-year BP Garth tsunami on the islands. The multi-period settlement site at Pool, on the low-lying island of Sanday (Fig. 5b), lies within an environment dominated by coastal dunes and shell-sand beaches (MacSween et al. 2015). Phase 2.1 of the occupation site, dated to around 4900-5900 years BP (29003900 BC) (probably 5000-5500 BC), is overlain by sandy deposit with 'stone spreads'. This is identified as an aeolian sand, although the presence of stones tends to negate such an interpretation. A later phase, 2.2, is also overlain by an apparent aeolian sand (Fig. 5c) (MacSween et al. 2015). There are two significant inconsistencies in the interpretation that these are wind-blown sediments. First, the stone spreads are unlikely to be aeolian. Second, if tsunami inundation had occurred, it would both destabilise and rework coastal dune deposits which would be its main sediment source. Similar scenarios have been reported elsewhere with a tsunami geomorphology imposed upon the coastal dune system, the development of an inland hummocky topography (akin to the nearubiquitous Machair on Sanday), and tsunami deposits comprised almost entirely of wind-blown sand (e.g. Goff et al. 2008b; McFadgen 2007).

Similar findings occur around the Bay of Skaill and Brodgar Isthmus (Fig. 5b). At the former, palaeoenvironmental records indicate that there was significant woodland 


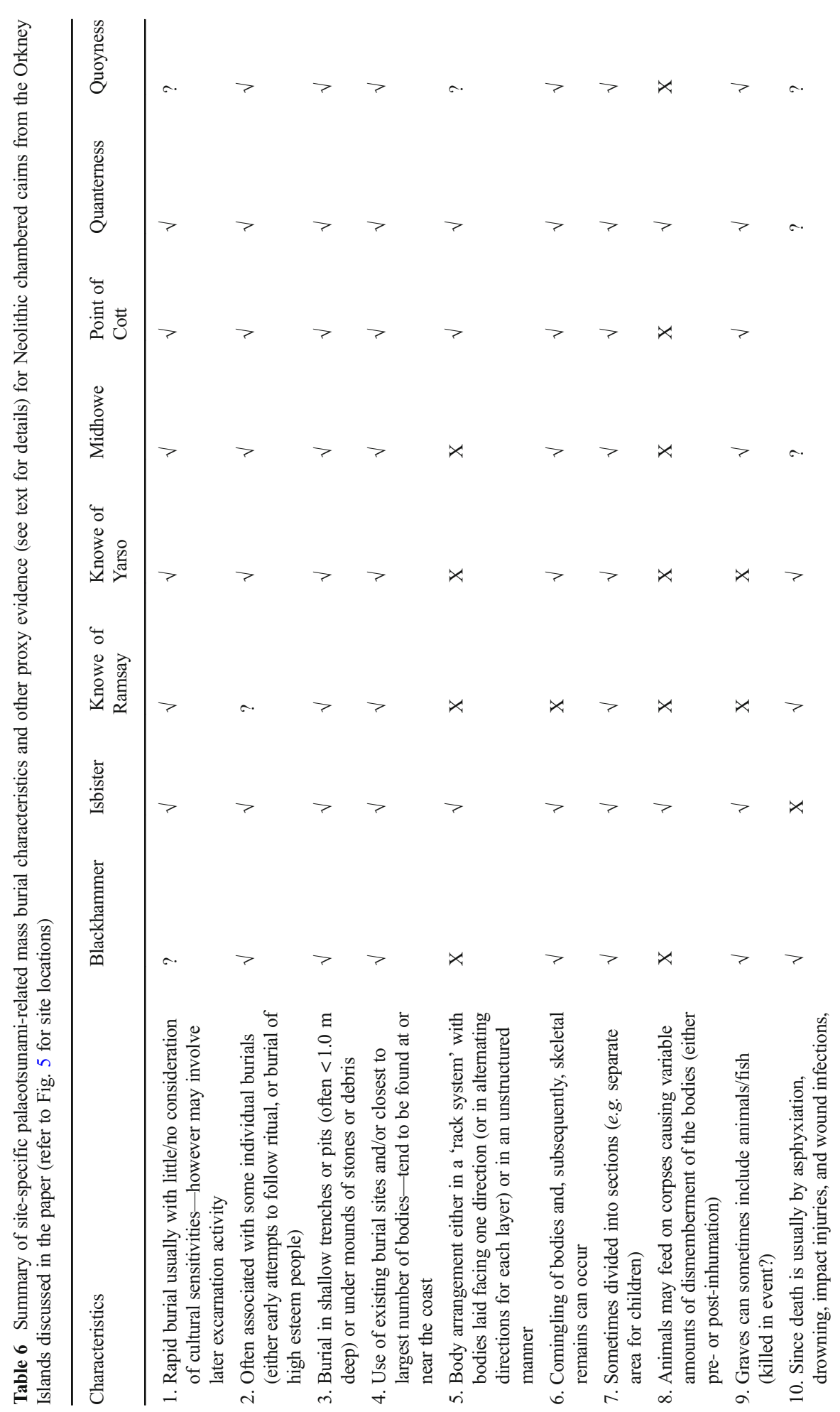




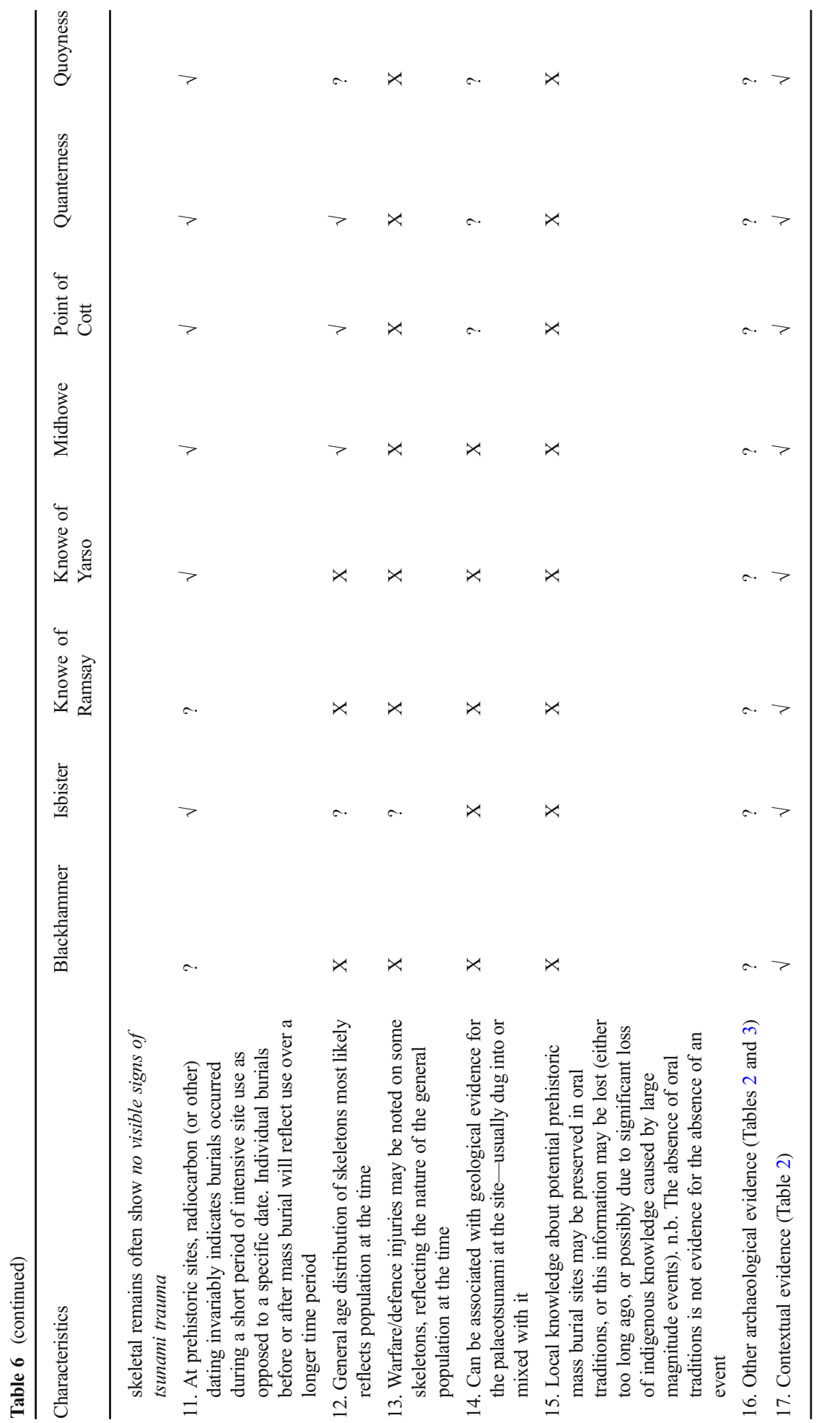


loss around 5500 years BP associated with a poorly dated influx of sand (de la VegaLeinert et al. 2000). While the mean grain size is that of a wind-blown sand, the wider grain size distribution of the deposit indicates that it was probably not. Furthermore, it extends as a sand sheet (not a wind-blown dune) up to $2 \mathrm{~km}$ inland. Any consideration that this might be related to the 5500-year BP Garth tsunami must take into account the work of Sorrel et al. (Sorrel et al. 2012) who identified a marked coincidence with a Holocene Storm Period (HSP) at this time. While their closest data point is from the Outer Hebrides, a region-wide effect has been noted (Sorrel et al. 2012). It is not necessary to invoke one or the other-storm or tsunami-as the key driver of these environmental changes, and it is plausible that they were caused by a combination of both. At the latter, Brodgar Isthmus, microfossil analysis and radiocarbon dates demonstrate that the Loch of Stenness, adjacent to the Brodgar Isthmus, was transformed from a freshwater to brackish environment during the early Neolithic at a time when there was a marked increase in sedimentation. It was inferred that this was probably related to occasional marine flooding during exceptional storm events (Bates et al. 2016). Given that the 5500-year BP Garth tsunami has been reported from the Shetland Islands (100 km NE) and that the Afen slide to the NW of both island archipelagos is a potential source, it remains to be seen whether further studies of the coastal sediments laid down in the early Neolithic may be related to one or both processes of storm and tsunami.

On balance, the archaeological data from Orkney's CCs may be considered equivocal, although the intense period of early Neolithic cairn construction and use suggests an unusual, possibly unique, catastrophic driver. This is a region that is relatively tectonically inactive, and as such, events like the tsunamigenic Storegga slide have left an indelible record in early Holocene sediments. In the absence of such a large subsequent event in the Holocene, geologists might be forgiven for not identifying the evidence for similar, but smaller events, especially at a time when there may have been a contemporaneous HSP. However, combining both sets of potentially circumstantial data from the archaeological and geological records, there is a case to be made for the possibility that there is a mass burial/tsunami linkage in the region. Is there any supporting archaeological data from Shetland that might strengthen this case?

\section{Mass Burials on Shetland}

Much of Shetland's landscape is covered in a thick blanket of peat, which means that the sandy evidence of past tsunami inundations is relatively easy to identify. Archaeologically though, the Neolithic period of Shetland is relatively poorly understood compared to the Orkney Islands (Doughton 2014; Sheridan 2012). Many of the cairns in Shetland are not well preserved (Hunt 1866; Tate 1886) which accounts for the poor dating control generally and makes estimates of the number of Neolithic sites difficult to determine (Fig. 4) (Doughton 2014). It appears that that the islands were somewhat isolated from mainland Scotland and Norway during the Neolithic period, and while Shetland cairns seem to have developed around the same time as those in Orkney, they are smaller (Kaul 2012). However, this may simply be a reflection of a smaller, isolated population. Difficulties in dating mean that differentiating between Neolithic and Bronze age tombs is problematic, but cairns include Caldback, Vementry, Ness of Nounsbrough, Punds Water, Islesburgh Ronas Hill, Swart-Houll, Knowe of Wilga, 
Gallow Hill (Unst—Fig. 4c), Huesbreck, Gallow Hill (Tingwall), Gallow Hill (Walls), Gallow Hill (Mainland), Ladie Hill, Burra Voe, Gulga, Gluss and Northmavine (Canmore 2017; Coolen 2012; Kaul 2012; Mahler 2012; Sheridan 2012) (Fig. 4).

In general, the chambered cairns of Shetland are either cruciform in shape with a small chamber (e.g. Vementry) or even smaller and more cist-like (e.g. Ronas Hill) (Doughton 2014). Sadly, not much can be said about the nature of the burials in these cairns since no human bone has ever been found in one. However, skeletal material from a cist site at Sumburgh on the very southern tip of Mainland, Shetland, suggests that mortuary practices were probably quite similar to those on Orkney (Doughton 2014).

The Sumburgh cist contained the comingled remains of up to 27 individuals, comprising both adult (10+), juvenile (4+) and neonatal (4+) members of both sexes (Hedges and Parry 1980; Walsh et al. 2012). Analysis of the skeletal material indicates that the individuals suffered from a range of traumas and diseases and that some of the bones were subject to weathering prior to deposition (Melton and Montgomery 2009). Indeed, there was some evidence of pitting and fracturing most likely associated with carnivore activity (dogs) (Walsh et al. 2012). Radiocarbon dating indicates that these burials date from the second half of the fourth millennium BC (3520-3340 BC) contemporaneous with those on Orkney.

Importantly, the cist comprises a stone-lined pit that had been dug into a layer of sand overlying the soil. Walsh et al. (Walsh et al. 2012) recognise that this sand equates to a similar deposit that occurs within a sequence of early middens exposed by coastal erosion at West Voe, some $400 \mathrm{~m} \mathrm{~S}$ of the burial site. They also note that the bodies must have been buried shortly after the deposition of the sands into which the pit had been cut (Walsh et al. 2012). Dates obtained from the lowest level of the West Voe midden sequence represent the earliest record of occupation on Shetland, around 42003600 BC (Melton 2009; Melton and Nicholson 2004), and prior to cist/cairn construction. The sand layer overlying these early midden deposits was laid down around 3500 BC (Gillmore and Melton 2011). The overlying midden dates to 3479-3275 years BP, contemporary with the Sumburgh cist burials (Gillmore and Melton 2011; Melton 2008, 2009; Melton and Nicholson 2004, 2007).

The older (4200-3600 BC), basal midden is comprised predominantly of oysters (Ostrea edulis) but also includes limpets (Patella vulgate) and mussels (Mytilus edulis), seal (Phocidae), sea-bird (e.g. Pinguinus impennis), terrestrial ungulate bones and potsherds. The younger (3479-3275 years BP), upper midden on the other hand is comprised entirely of cockles (Cerastoderma edule) (Gillmore and Melton 2011). Such a marked change in midden composition has been widely noted in New Zealand archaeology where midden layers are separated by palaeotsunami sediments (e.g. McFadgen 2007). These changes indicate that nearshore substrates changed instantly from bedrock to sand or vice versa as sediment was rapidly redistributed by high-energy tsunami waves (McFadgen and Goff 2007).

In the case of West Voe, oysters, limpets and mussels point to a rocky substrate, whereas cockles are active suspension feeders, living in the top few centimetres of what is normally a clean sand (Ducrotoy et al. 1991; Global Invasive Species Database 2017). Furthermore, cockles are easily dislodged by storms which suggests that while there may have been increased storminess around this time (Sorrel et al. 2012; Walsh et al. 2012), these storms are unlikely to have significantly affected this area. An examination 
of the sand layer separating the two middens was restricted to the West Voe site and so no lateral variations are known. However, it was comprised of a structureless, normally graded (fining-upwards) medium sand with shallow water benthic foraminifera that are not typical in aeolian sediments (Gillmore and Melton 2011).

It is highly likely that this is another example of the 5500-year BP Garth tsunami deposit (Fig. 4) comprised of sand sourced from immediately offshore from the then rocky coast or reworking a coastal dune system that has since been completely eroded. Indeed, in considering these data from West Voe, Gillmore and Melton (2011) noted that if the sand was associated with a tsunami, then the implications for human settlement would be significant.

This archaeological assemblage links a well-dated midden at West Voe that records significant environmental changes caused by the probable 5500-year BP Garth tsunami with that of the Sumburgh cist burials that took place immediately after the event. When placed within the wider regional picture of the (near?) contemporaneous construction of chambered cairns on both Orkney and Shetland, it provides a compelling case for suggesting that many of these mass burials may indeed be the result of a catastrophic tsunami. This does not require all the CCs to be mass burials related to this event and it does not mean that they were used solely for that purpose, but it does suggest that these monumental structures on both Orkney and Shetland may well be archaeological evidence for palaeotsunami inundation.

\section{A Way Forward}

Studies of mass burial sites provide excellent examples of the skills of archaeological fieldwork and narrative interpretation. However, often the raison d'etre for the mass burial in question is difficult to determine - if it fails to fall into an easily recognisable category such as sacrifice, war, famine, plague or possibly an occasional natural disaster such as an earthquake, then the huge amounts of archaeological data quite naturally become the focus for detailed study. These data allow commendable speculation about diverse topics such as variations in burial position, mortuary practices, status and grave goods, diet, general living conditions, community structure and so on. Indeed, the complex nature of the deposits associated with mass burials means that one explanation is often not sufficient to satisfy archaeological enquiry (Reilly 2003).

It is often the statistical manipulation of radiocarbon dates that serve to muddy the waters of mass burials. Invariably, calibrated age ranges obtained from a variety of dateable material associated with a mass burial (or mass burials) tend to overlap. Outliers are easy to identify and as such often easy to interpret. However, do these overlapping ages indicate a one-off burial phase or not? Statistical analyses are often used to tease out potentially subtle differences in age ranges and therefore support the argument that burials occurred over a short, but relatively intensive period of a few hundred years or so-in other words a regular cemetery if you wish as opposed to a mass grave. While this is a perfectly reasonable line to pursue, it is usually done at the expense of the alternative and entirely reasonable hypothesis that the burials relate to a single event and that the overlap in radiocarbon dates is real. 
It is important to recognise that many prehistoric or early historical mass burials have been reported around the world, and as noted above, there are numerous easily recognisable categories that provide explanations for why they exist. However, it is all too easy to pursue an explanation that sits within the existing paradigm and, with the exception perhaps of the Japanese work (Minami et al. 2012), fail to recognise the signs that may point towards an alternative interpretation such as that of a tsunami. In a pre-2004 IOT world, this might have been acceptable, but we now have experience of how these events can be devastatingly catastrophic for modern coastal communities let alone more ancient ones. We have highlighted many potential pointers or characteristics of what could constitute evidence for a palaeotsunami in both geological and archaeological frameworks in order to show the interrelated signals of catastrophic human-environment interactions. However, as we have worked through numerous examples in this paper, it has become apparent that it is difficult to find sufficient detail from any one site or region to be categorical in determining a tsunami link with a mass burial. In many ways, this is because no one has been looking for the type of evidence necessary or has assembled the data in such a manner that allows this scenario to be considered.

There is undoubtedly a much more acceptable case to be made for a tsunami-mass burial link in tectonically active areas (e.g. Pacific: Solomon Islands, Vanuatu; Mediterranean: Greece) as opposed to less active areas like the northern Atlantic. The argument here is not that every mass burial is tsunami-related, but that in a coastal context in particular, there is the danger of not considering it and, as such, misinterpreting much about human-environment interactions in prehistory. As noted in the Vanuatu research, there is an equifinality issue here (Valentin et al. 2010). Archaeological manifestations of different mortuary practices may be similar and so all potential explanations need to be explored.

Numerous arguments can be presented to question our interpretations for one or many of the sites discussed above, but there is an additional test that has, as yet, never been applied to a study of prehistoric or early historical coastal mass burials. The main (but not only) cause of death in a tsunami is by asphyxiation. Asphyxiation occurs as large amounts of water are inhaled into the respiratory tract and lungs. As the lungs fill with water, the alveolar walls burst and diatoms (microfossils) in the water enter the blood and can be transported around the body into the bone marrow (Carlie et al. 2014). Diatoms are microscopic algae and there are more than 15,000 species living either in fresh, brackish or salt water. Importantly, they are not present inside the skeletal remains of a person who did not drown, and furthermore, they are extremely resistant to putrefaction which allows post-mortem extraction (Delabarde et al. 2013). As such, the use of diatom analysis to establish drowning as the cause of death is a regularly used and proven test in forensic archaeology (Carlie et al. 2014; Vinayak et al. 2010). For skeletonised remains (such as those found in prehistoric and early historical mass burials), it is considered best to assess the femoral bone marrow (Delabarde et al. 2013; Vinayak et al. 2010), although analysis of diatoms from the right humerus of a Late Neolithic child's skeleton in Sweden indicated that the child had died by drowning and had not simply been disposed of after death (Carlie et al. 2014).

In the case of mass burials, it is notable that skeletal remains may not always be sufficiently well preserved for such a test to be performed. However, allowing for 
the vagaries of mortuary practices, it is more likely that the larger bones of the femora and humeri will be preferentially preserved. As such, the diatom analysis regularly performed in a variety of other forensic archaeological scenarios may be well suited to potentially providing a simple test as to whether a mass burial contains asphyxiated victims. Careful selection of the number and state of preservation of skeletal material to be analysed will be important, but when used in conjunction with other criteria discussed in the text, it is likely to prove invaluable in determining whether asphyxiation was caused by tsunami, storm or freshwater flood. We suggest that where possible this simple analysis should be carried out on skeletal remains from the sites discussed in this paper prior to proposing numerous arguments attempting to negate our suggested interpretations. Furthermore, it should become a standard technique in the archaeological investigation of all coastal burial sites.

\section{Conclusions}

Recent catastrophic events such as the 2004 IOT and 2011 ToT have had a profound effect on modern coastal communities with death tolls in the tens of thousands. This therefore provides an opportunity to consider the significance of such events in the prehistoric and early historical record. Alternative assessments of Northern and Southern Hemisphere coastal mass burial sites in both tectonically active and relatively inactive regions have been presented. In many cases, the fundamental question of why there could have been a mass burial at a specific site at a particular time has never been satisfactorily addressed. We have attempted to put a framework around the key archaeological and geological criteria that can assist in interpreting a site and have assessed many of the mass burials discussed in the text against them. Often the data are not available to effectively address the question because the research carried out did not consider such a scenario. While this is understandable for work carried out prior to the 2004 IOT, it is a notable omission from more recent research.

Finding palaeotsunami evidence that is contemporaneous with a coastal mass burial(s) is an important step in making a link between them. In some cases, the geological record for a contemporaneous palaeotsunami can be lost through taphonomic processes, but the effect of it on the coastal human population at the time may be preserved in a more enduring form such as a mass burial, with or without any additional associated archaeological/anthropological evidence. The key point is that finding evidence for past tsunamis does not rest solely in the domain of the geologist but rather across the disciplinary divides of geology, geomorphology, archaeology and anthropology. As an example of a catastrophic humanenvironment interaction, it could be argued that archaeologists, like geologists, should be able to identify evidence for past tsunami inundation of ancient coastal communities. Coastal mass burials are a perfect example of where significant strides can be made, initially perhaps with the simplest of diatom tests on skeletal remains from existing sites. For example, if even a single mass burial site can be linked to a palaeotsunami, it will fundamentally rewrite how we interpret coastal human settlement in prehistory. 
Open Access This article is distributed under the terms of the Creative Commons Attribution 4.0 International License (http://creativecommons.org/licenses/by/4.0/), which permits unrestricted use, distribution, and reproduction in any medium, provided you give appropriate credit to the original author(s) and the source, provide a link to the Creative Commons license, and indicate if changes were made.

\section{References}

Alam, E., Dominey-Howes, D., Chagué-Goff, C., \& Goff, J. (2012). Tsunamis of the northeast Indian Ocean with a particular focus on the Bay of Bengal region-a synthesis and review. Earth-Science Reviews, 114(1-2), 175-193.

Altinok, Y., Alpar, S. B., Yaltırak, C., \& Kıyak, N. G. (2009). Investigations of historical earthquakes and tsunamis in the Gulf of Saros, NW Turkey. International Symposium on Historical Earthquakes and Conservation of Monuments and Sites in the Eastern Mediterranean Region, 500th Anniversary Year of the 1509 September 10, Marmara Earthquake, Turkey, 10-12 September 2009.

Altinok, Y., Alpar, S. B., Ozer, N., \& Vardar, H. (2011). Revision of the tsunami catalogue affecting Turkish coasts and surrounding regions. Natural Hazards and Earth System Sciences, 11(2), 273-291.

Altinok, Y., Alpar, S. B., Yaltirak, C., Kiyak, N. G., \& Zabci, C. (2013). Tsunami effects on the eastern coast of Saros Bay, Turkey. 40th CIESM Congress Proceedings, Marseilles: France.

Anderson, A. (2009). Epilogue: Changing archaeological perspectives upon historical ecology in the Pacific Islands. Pacific Science, 63(4), 747-757.

Atwater, B. F. (1987). Evidence for great Holocene earthquakes along the outer coast of Washington State. Science, 236(4804), 942-944.

Barber, J. (1988). Isbister, Quanterness and the Point of Cott: the formulation and testing of some middle range theory. In J. C. Barrett \& I. A. Kinnes (Eds.), The archaeology of context in the Neolithic and Bronze Age: recent trends (pp. 57-62). Sheffield: University of Sheffield.

Barber J. (1997). The excavation of a stalled cairn at the Point of Cott. Westray, Orkney. Scottish Trust for Archaeological Research, Monograph No. 1: Edinburgh.

Bates, C. R., Bates, M. R., Dawson, S., Huws, D., Whittaker, J. E., \& Wickham-Jones, C. R. (2016). The environmental context of the Neolithic monuments on the Brodgar Isthmus, Mainland, Orkney. Journal of Archaeological Science, 7, $394-407$.

Bedford, S., \& Spriggs, M. (2007). Birds on the rim: a unique Lapita carinated vessel in its wider context. Archaeology in Oceania, 42(1), 12-21.

Bedford, S., Spriggs, M., \& Regenvanu, R. (2006). The Teouma Lapita site and the early human settlement of the Pacific Islands. Antiquity, 80(310), 812-828.

Bedford, S., Spriggs, M., Buckley, H., Valentin, F., \& Regenvanu, R. (2009). The Teouma Lapita site, South Efate, Vanuatu: a summary of three field seasons (2004-2006). In P. Sheppard, T. Thomas, \& G. Summerhayes (Eds.), Lapita: ancestors and descendants (pp. 215-234). Auckland: New Zealand Archaeological Association Monograph Series.

Bondevik, S., Svendsen, J. I., \& Mangerud, J. A. (1997). Tsunami sedimentary facies deposited by the Storegga tsunami in shallow marine basins and coastal lakes, western Norway. Sedimentology, 44(6), 1115-1131.

Bondevik, S., Mangerud, J., Dawson, S., Dawson, A., \& Lohne, Ø. (2003). Record-breaking height for 8000year-old tsunami in the North Atlantic. Eos, Transactions American Geophysical Union, 84(31), 289293.

Bondevik, S., Løvholt, F., Harbitz, C., Mangerud, J., Dawson, A., \& Svendsen, J. I. (2005a). The Storegga Slide tsunami-comparing field observations with numerical simulations. Marine and Petroleum Geology, 22(1-2), 195-208.

Bondevik, S., Mangerud, J., Dawson, S., Dawson, A., \& Lohne, Ø. (2005b). Evidence for three North Sea tsunamis at the Shetland Islands between 8000 and 1500 years ago. Quaternary Science Reviews, 24 (14 15), 1757-1775.

Brill, D., May, S. M., Engel, M., Reyes, M., Pint, A., Opitz, S., Dierick, M., Gonzalo, L. A., Esser, S., \& Brückner, H. (2016). Typhoon Haiyan's sedimentary record in coastal environments of the Philippines and its palaeotempestological implications. Natural Hazards and Earth System Sciences, 16(12), 27992822.

Bruins, H. J., \& van der Plicht, J. (2014). The Thera olive branch, Akrotiri (Thera) and Palaikastro (Crete): comparing radiocarbon results of the Santorini eruption. Antiquity, 88(339), 282-287. 
Buckley, H. R., \& Tayles, N. (2003). Skeletal pathology in a prehistoric Pacific Island sample: issues in lesion recording, quantification, and interpretation. American Journal of Physical Anthropology, 122(4), 303324.

Callander, J. G., \& Grant, W. G. (1934). A long stalled chambered cairn or mausoleum (Rousay type) near Midhowe, Rousay, Orkney. Proceedings of the Society of Antiquaries of Scotland, 68, 320-350.

Callander, J. G., \& Grant, W. G. (1935). The Knowe of Yarso. Proceedings of the Society of Antiquaries of Scotland, 69, 325-351.

Callander, J. G., \& Grant, W. G. (1937). Long stalled cairn at Blackhammer, Rousay, Orkney. Proceedings of the Society of Antiquaries of Scotland, 71, 297-308.

Canmore. (2017). The online catalogue to Scotland's archaeology, buildings, industrial and maritime heritage. https://canmore.org.uk/. Accessed 27 April 2017.

Carlie, A., Arcini, C., Druid, H., \& Risberg, J. (2014). Archaeology, forensics and the death of a child in Late Neolithic Sweden. Antiquity, 88(342), 1148-1163.

Chagué-Goff, C., Schneider, J. L., Goff, J. R., Dominey-Howes, D., \& Strotz, L. (2011). Expanding the proxy toolkit to help identify past events-lessons from the 2004 Indian Ocean tsunami and the 2009 South Pacific tsunami. Earth-Science Reviews, 107(1-2), 107-122.

Chamberlin, T. C. (1890). The method of multiple working hypotheses. Science, 15, 92-96.

Chesterman, J. T. (1979). Investigation of the human bones from Quanterness. In C. Renfrew (Ed.), Investigations in Orkney (pp. 97-111). Society of Antiquaries: London.

Chesterman, J. T. (1983). The human remains. In Hedges, J.W. Isbister: a chambered tomb in Orkney (pp. 73132). British Archaeological Reports, Series 115: Oxford.

Childe, V. G. (1952). Re-excavation of the chambered cairn of Quoyness, Sanday, on the behalf of the Ministry of Works. Proceedings of the Society of the Antiquaries of Scotland, 86, 121-140.

Cole, J. (2017). Assessing the calorific significance of episodes of human cannibalism in the Palaeolithic. Scientific Reports, 7, 44707.

Coolen, J. A. (2012). Survey of Shetland's Gallow hills. TAP Field Report No. 5.

Crozier, R. (2016). Fragments of death. A taphonomic study of human remains from Neolithic Orkney. Journal of Archaeological Science: Reports, 10, 725-734.

Dan, G., Sultan, N., \& Savoye, B. (2007). The 1979 Nice harbour catastrophe revisited: trigger mechanism inferred from geotechnical measurements and numerical modelling. Marine Geology, 245(1-4), 40-64.

Davidson, J. L., \& Henshall, A. S. (1989). The chambered cairns of Orkney. Edinburgh: Edinburgh University Press.

Dawson, S., \& Smith, D. E. (2000). The sedimentology of Middle Holocene tsunami facies in northern Sutherland, Scotland, UK. Marine Geology, 170(1-2), 69-79.

Dawson, A. G., Dawson, S., \& Bondevik, S. (2006). A late Holocene tsunami at Basta Voe, Yell, Shetland Isles. Scottish Geographical Journal, 122(2), 100-108.

de la Vega-Leinert, A. C., Keen, D. H., Jones, R. L., Wells, J. M., \& Smith, D. E. (2000). Mid-Holocene environmental changes in the Bay of Skaill, Mainland Orkney, Scotland: an integrated geomorphological, sedimentological and stratigraphical study. Journal of Quaternary Science, 15(5), 509-528.

Delabarde, T., Keyser, C., Tracqui, A., Charabidze, D., \& Ludes, B. (2013). The potential of forensic analysis on human bones found in riverine environment. Forensic Science International, 228(1-3), e1-e5.

Doughton, L. (2014). A most curious class of small cairn: reinterpreting the burnt mounds of Shetland. Unpublished $\mathrm{PhD}$ thesis, University of Manchester. $301 \mathrm{pp}$.

Ducrotoy, C. R., Rybarczyk, H., Souprayen, J., Bachelet, G., Beukema, J. J., Desprez, M., Dõrjes, J., Essink, K., Guillou, J., Michaelis, H., Sylvand, B., Wilson, J. G., Elkaïm, B., \& Ibanez, F. (1991). A comparison of the population dynamics of the cockle (Cerastoderma edule) in North-Western Europe. In Estuaries and Coasts: Spatial and Temporal Intercomparisons, (pp. 173-184). Proceedings of the Estuarine and Coastal Sciences Association Symposium, ECSA 19, 4-8 September 1989, University of Caen, France. Denmark: Olsen \& Olsen.

Dudley, W. C., Whitney, R., Faasisila, J., Fonolua, S., Jowitt, A., \& Chan-Kau, M. (2011). Learning from the victims: new physical and social science information about tsunamis from victims of the September 29, 2009 event in Samoa and American Samoa. Earth Science Reviews, 107(1), 201-206.

Fritz, H. M., Mohammed, F., \& Yoo, J. (2009). Lituya Bay landslide impact generated mega-tsunami 50th anniversary. Pure and Applied Geophysics, 166(1-2), 153-175.

Frohlich, C., Hornbach, M. J., Taylor, F. W., Shen, C. C., Moala, A., Morton, A. E., \& Kruger, J. (2009). Huge erratic boulders in Tonga deposited by a prehistoric tsunami. Geology, 37(2), 131-134.

Gelfenbaum, G., \& Jaffe, B. (2003). Erosion and sedimentation from the 17 July, 1998 Papua New Guinea tsunami. Pure and Applied Geophysics, 160(10-11), 1969-1999. 
Gillmore, G. K., \& Melton, N. (2011). Early Neolithic sands at West Voe, Shetland Islands: implications for human settlement. Geological Society London, Special Publications., 352(1), 69-83.

Global Invasive Species Database. (2017). Species profile: Ostrea edulis. http://www.iucngisd. org/gisd/species.php?sc=798. Accessed 2 September 2017.

Goff, J., \& McFadgen, B. G. (2001). Catastrophic seismic-related events and their impact on prehistoric human occupation in coastal New Zealand. Antiquity, 74, 155-162.

Goff, J., \& McFadgen, B. G. (2003). Large earthquakes and the abandonment of prehistoric coastal settlements in $15^{\text {th }}$ century New Zealand. Geoarchaeology, 18(6), 609-623.

Goff, J., \& Nunn, P. (2016). Rapid societal change as a proxy for regional environmental forcing: evidence and explanations for Pacific Island societies in the 14-15 ${ }^{\text {th }}$ centuries. Island Arc, 25(5), 305-315.

Goff, J., \& Sugawara, D. (2014). Seismic driving of sand beach ridge formation in northern Honshu, Japan. Marine Geology, 358, 138-149.

Goff, J., Chagué-Goff, C., \& Nichol, S. (2001). Palaeotsunami deposits: a New Zealand perspective. Sedimentary Geology, 143(1-2), 1-6.

Goff, J., McFadgen, B. G., \& Chagué-Goff, C. (2004). Sedimentary differences between the 2002 Easter storm and the $15^{\text {th }}$ century Okoropunga tsunami, southeastern North Island, New Zealand. Marine Geology, 204(1-2), 235-250.

Goff, J., Charley, D., Haruel, C., \& Bonte-Grapentin, M. (2008a). Preliminary findings of the geological evidence and oral history of tsunamis in Vanuato. SOPAC Technical Report No. 416, 49.

Goff, J., McFadgen, B. G., Wells, A., \& Hicks, M. (2008b). Seismic signals in coastal dune systems. Earth Science Reviews, 89(1-2), 73-77.

Goff, J., Nichol, S. L., Chagué-Goff, C., Horrocks, M., McFadgen, B., \& Cisternas, M. (2010). Predecessor to New Zealand's largest historic trans-South Pacific tsunami of 1868AD. Marine Geology, 275(1-4), 155165.

Goff, J., Chagué-Goff, C., Dominey-Howes, D., McAdoo, B., Cronin, S., Bonté-Grapetin, M., Nichol, S., Horrocks, M., Cisternas, M., Lamarche, G., Pelletier, B., Jaffe, B., \& Dudley, W. (2011a). Palaeotsunamis in the Pacific Islands. Earth-Science Reviews, 107(1-2), 141-146.

Goff, J., Lamarche, G., Pelletier, B., Chagué-Goff, C., \& Strotz, L. (2011b). Palaeotsunami precursors to the 2009 South Pacific tsunami in the Wallis and Futuna archipelago. Earth Science Reviews, 107(1-2), 91106.

Goff, J., Chagué-Goff, C., Nichol, S. L., Jaffe, B., \& Dominey-Howes, D. (2012a). Progress in palaeotsunami research. Sedimentary Geology, 243-244, 70-88.

Goff, J., McFadgen, B. G., Chagué-Goff, C., \& Nichol, S. L. (2012b). Palaeotsunamis and their influence on Polynesian settlement. The Holocene, 22, 1061-1063.

Goff, J., Terry, J., Chagué-Goff, C., \& Goto, K. (2014). What is a megatsunami? Marine Geology, 358, $12-17$.

Goodenough, W. H. (1955). A problem in Malayo-Polynesian social organization. American Anthropologist, 57(1), 71-83.

Goto, K., Chagué-Goff, C., Fujino, S., Goff, J., Jaffe, B., Nishimura, Y., Richmond, B., Suguwara, D., Szczuciński, W., Tappin, D. R., Witter, R., \& Yulianto, E. (2011). New insights into tsunami risk from the 2011 Tohoku-oki event. Marine Geology, 290(1-4), 46-50.

Grapes, R., \& Downes, G. (1997). The 1855 Wairarapa, New Zealand, earthquake — analysis of historical data. Bulletin of the New Zealand Society for Earthquake Engineering, 30, 271-368.

Grapes, R., \& Goh, A. (1998). Marlborough: one hundred and fifty years of earthquakes. Family histories of the Marlborough area. Marlborough: Marlborough Historical Society.

Haflidason, H., Lien, R., Sejrup, H. P., Forsberg, C. F., \& Bryn, P. (2005). The dating and morphometry of the Storegga Slide. Marine and Petroleum Geology, 22(1-2), 123-136.

Heaton, T. H., \& Snavely Jr., P. D. (1985). Possible tsunami along the northwestern coast of the United States inferred from Indian traditions. Bulletin of the Seismological Society of America, 75, 1455-1460.

Hedges, J. W. (1983). Isbister: a chambered tomb in Orkney. British Archaeological Reports, Series 115: Oxford.

Hedges, J. W., \& Parry, G. A. (1980). A Neolithic multiple burial from Sumburgh, Shetland. Glasgow Archaeological Journal, 7(7), 15-26.

Henshall, A. S. (1963). The chambered tombs of Scotland. Volume 1. Edinburgh: Edinburgh University Press. Henshall, A. S. (1972). The chambered tombs of Scotland. Volume 2. Edinburgh: Edinburgh University Press. Hirano, K. (2013). Difficulties in post-tsunami reconstruction plan following Japan's 3.11 mega disaster: dilemma between protection and sustainability. Journal of JSCE, 1(1), 1-11.

Hogbin, H. I. (1931). The social organization of Ontong Java. Oceania, 1(4), 399-425. 
Hunt, J. (1866). Report on explorations into the archaic anthropology of the islands of Unst, Bressay, and the mainland of Zetland, undertaken for the Earl of Zetland and the Anthropological Society of London. Memoirs read before the Anthropological Society of London, 2, 294-338.

Hutchinson, I., \& McMillan, A. D. (1997). Archaeological evidence for village abandonment associated with late Holocene earthquakes at the northern Cascadia subduction zone. Quaternary Research, 48(01), 7987.

Iida, K. (1984). Catalog of Tsunamis in Japan and its neighboring countries. Special report, Aichi Institute of Technology, Japan.

Ishizawa, T., Watanabe, M., Goto, K., Ikehara, K., Walls, S., \& Iryu, Y. (2016). Traces of paleotsunamis in the Shetland Islands. Geology Magazine, 122, 1-2.

Jones, W. H. S. (1918). Pausanias: description of Greece, Volume I, Books I and II (Attica, Corinth). Loeb Classical Library. William Heinemann; GP Putnam's Sons.

Kaul, F. (2012). Multi-period constructions of megalithic tombs — and the megalithic tombs in Shetland. In D. L. Mahler (Ed.), The border of farming and the cultural markers. Short papers from the network meeting in Lerwick, Shetland (pp. 100-121). Copenhagen: The National Museum of Denmark.

Keim, M. E. (2006). Cyclones, tsunamis and human health. Oceanography, 19(2), 40-49.

Kinaston, R., Buckley, H., Halcrow, S., Spriggs, M., Bedford, S., \& Gray, A. (2009). Investigating foetal and perinatal mortality and morbidity in prehistoric skeletal samples. Journal of Archaeological Science, 36(12), 2780-2787.

King, D., \& Goff, J. (2010). Benefitting from differences in knowledge, practice and belief: Māori oral traditions and natural hazards science. Natural Hazards and Earth System Sciences, 10(9), 1927-1940.

King, D. N., Goff, J., \& Skipper, A. (2007). Māori environmental knowledge and natural hazards in Aotearoa New Zealand. Journal of the Royal Society of New Zealand, 37(2), 59-73.

King, D. N., Goff, J., Chagué-Goff, C., McFadgen, B., Jacobsen, G., Gadd, P., \& Horrocks, M. (2017). Reciting the layers: evidence of past tsunamis at Mataora - Wairau Lagoon, Aotearoa - New Zealand. Marine Geology, 389, 1-16.

Kirch, P. V. (2010). Peopling of the Pacific: a holistic anthropological perspective. Annual Review of Anthropology, 39, 131-148.

Kondo T. (2018). Planning challenges for housing and built environment recovery after the great East Japan earthquake: collaborative planning and management go beyond government-driven redevelopment projects. In V. Santiago-Fandiño, S. Sato, N. Maki \& K. Iuchi (Eds.), The 2011 Japan Earthquake and Tsunami: reconstruction and restoration (pp. 155-169). Advances in natural and technological hazards research, vol. 47. Cham: Springer.

Lawrence, D. M. (2012). Orkney's first farmers. Reconstructing biographies from osteological analysis to gain insights into life and society in a Neolithic community on the edge of Atlantic Europe. Unpublished $\mathrm{PhD}$ thesis, University of Bradford. $651 \mathrm{pp}$.

Leach, B., \& Davidson, J. (2008). The archaeology of Taumako. Wellington: New Zealand Journal of Archaeology Special Publication.

Liou, Y. A., Sha, H. C., Chen, T. M., Wang, T. S., Li, Y. T., Lai, Y. C., Chiang, M. H., \& Lu, L. T. (2012). Assessment of disaster losses in rice paddy field and yield after tsunami induced by the 2011 great East Japan earthquake. Journal of Marine Science and Technology, 20, 618-623.

Little, L. M., \& Papadopoulos, J. K. (1998). A social outcast in early Iron Age Athens. Hesperia: The Journal of the American School of Classical Studies at Athens, 67(4), 375-404.

Liu, P. L.-F., Lynett, P., Fernando, J., Jaffe, B. E., Fritz, H., Higman, B., Morton, R., Goff, J., \& Synolakis, C. (2005). Observations by the International Tsunami team in Sri Lanka. Science, 308(5728), 1595.

Loe, L., Boyle, A., Webb, H., \& Score, D. (2014). 'Given to the ground': a Viking age mass grave on Ridgeway Hill, Weymouth. Dorset Natural History and Archaeological Society Monograph Series, No. $22,303$.

Long D., Stevenson A. G., Wilson C. K., \& Bulat J. (2003). Slope failures in the Faroe - shetland channel. In J. Locat, J. Mienert \& L. Boisvert (Eds.), Submarine mass movements and their consequences (pp. 281289). Advances in natural and technological hazards research, vol. 19. Dordrecht: Springer.

Long, A. J., Barlow, N. L., Dawson, S., Hill, J., Innes, J. B., Kelham, C., Milne, F. D., \& Dawson, A. (2016). Lateglacial and Holocene relative sea-level changes and first evidence for the Storegga tsunami in Sutherland, Scotland. Journal of Quaternary Science, 31(3), 239-255.

Longva O., Janbu N., Blikra L. H., \& Bøe R. (2003). The 1996 Finneidfjord slide; seafloor failure and slide dynamics. In J. Locat, J. Mienert \& L. Boisvert (Eds.), Submarine mass movements and their consequences (pp. 531-538). Advances in natural and technological hazards research, vol. 19. Dordrecht: Springer. 
Løvholt, F. S., Bondevik, S., Laberg, J. S., Kim, J., \& Boylan, N. (2017). Some giant submarine landslides do not produce large tsunamis. Geophysical Research Letters, 44(16), 8463-8472. https://doi.org/10.1002 /2017GL074062.

Macsween, A., Hunter, J., Sheridan, A., Bond, J., Ramsey, C. B., Reimer, P., Bayliss, A., Griffiths, S., \& Whittle, A. (2015). Refining the chronology of the Neolithic settlement at Pool, Sanday, Orkney: implications for the emergence and development of grooved ware. Proceedings of the Prehistoric Society, 81, 283-310.

Mahler, D. L. (2012). Pinhoulland - a multi period site from West Mainland, Shetland. Some features of the Neolithic of Shetland. In D. L. Mahler (Ed.), The border of farming and the cultural markers (pp. 37-52). Short Papers from the network meeting in Lerwick, Shetland). Copenhagen: The National Museum of Denmark.

Matsumoto, H., Yoshida, M., \& Kumagai, M. (2012). Paleo-tsunami and the 2011 tsunami deposits on the Sendai Coastal Lowland, Northeast Japan. Transactions of the Japanese Geomorphological Union, 33, 385-389.

Max Plank Institute for the Science of Human History. (2017). Vietnam to Vanuatu: dental calculus and the Austronesian expansion. https:/www.shh.mpg.de/314001/Tromp-Vietnam-to-Vanuatu. Accessed 27 August 2017.

McAdoo, B. G., Dengler, L., Prasetya, G., \& Titov, V. (2006). Smong: how an oral history saved thousands on Indonesia's Simeulue Island during the December 2004 and March 2005 tsunamis. Earthquake Spectra, 22(S3), 661-669.

McFadgen, B. G. (2007). Hostile shores: catastrophic events in prehistoric New Zealand and their impact on Mãori coastal communities. Auckland: Auckland University Press.

McFadgen, B. G., \& Goff, J. (2005). An earth systems approach to understanding the tectonic and cultural landscapes of linked marine embayments: Avon-Heathcote Estuary (Ihutai) and Lake Ellesmere (Waihora), New Zealand. Journal of Quaternary Science, 20(3), 227-237.

McFadgen, B. G., \& Goff, J. (2007). Tsunamis in the archaeological record of New Zealand. Sedimentary Geology, 200(3-4), 263-274.

McMillan, A. D., \& Hutchinson, I. (2002). When the mountain dwarfs danced: aboriginal traditions of paleoseismic events along the Cascadia subduction zone of western North America. Ethnohistory, 49(1), 41-68.

McSaveney, M., Goff, J., Darby, D., Goldsmith, P., Barnett, A., Elliott, S., \& Nongkas, M. (2000). The 17th July 1998 tsunami, Sissano Lagoon, Papua New Guinea-evidence and initial interpretation. Marine Geology, 170(1-2), 81-92.

Melton, N. D. (2008). West Voe: a Mesolithic-Neolithic transition site in Shetland. In G. Noble, T. Poller, J. Raven, \& L. Verrill (Eds.), Scottish odysseys: the archaeology of islands (pp. 23-36). Stroud: Tempus.

Melton, N. D. (2009). Shells, seals and ceramics: an evaluation of a midden at West Voe, Sumburgh, Shetland, 2004-2005. In S. McCartan \& P. Woodman (Eds.), Mesolithic horizons: papers presented at the seventh international conference in Europe, Belfast 2005 (pp. 184-189). Oxford: Oxbow.

Melton, N., \& Montgomery, J. (2009). Combined isotope analyses of Early Neolithic individuals from a multiple burial cist at Sumburgh, Shetland. Discovery and Excavation in Scotland, 10, 167.

Melton, N. D., \& Nicholson, R. A. (2004). The Mesolithic in the Northern Isles: the preliminary evaluation of an oyster midden at West Voe, Sumburgh, Shetland, UK. Antiquity 78, 299. http://www.antiquity.ac. uk/projgall/nicholson/. Accessed 2 September 2017.

Melton, N. D., \& Nicholson, R. A. (2007). A late Mesolithic-Early Neolithic midden at West Voe, Shetland. In N. Milner, O. E. Craig, \& G. N. Bailey (Eds.), Shell middens in Atlantic Europe (pp. 94-100). Oxford: Oxbow.

Meyer, C., Lohr, C., Gronenborn, D., \& Alt, K. W. (2015). The massacre mass grave of SchöneckKilianstädten reveals new insights into collective violence in Early Neolithic Central Europe. Proceedings of the National Academy of Sciences, 112(36), 11217-11222.

Minami, M., Nakamura, T., Nagaoka, T., \& Hirata, K. (2012). 14 C dating human skeletons from medieval Archaelogical sites in Kamakura, Japan: were they victims of Nitta Yoshisada's attack? Radiocarbon, 54(3-4), 599-613.

Morgan, O. W., Sribanditmongkol, P., Perera, C., Sulasmi, Y., Van Alphen, D., \& Sondorp, E. (2006). Mass fatality management following the South Asian tsunami disaster: case studies in Thailand, Indonesia, and Sri Lanka. PLoS Medicine, 3, e195.

Morton, R. A., Gelfenbaum, G., \& Jaffe, B. E. (2007). Physical criteria for distinguishing sandy tsunami and storm deposits using modern examples. Sedimentary Geology, 200(3-4), 184-207.

Nagaoka, T., \& Hirata, K. (2006). Tooth size of the Medieval period people of Japan. Anthropological Science, 114(2), 117-126. 
Newman, A. V., Feng, L., Fritz, H. M., Lifton, Z. M., Kalligeris, N., \& Wei, Y. (2011). The energetic 2010 MW 7.1 Solomon Islands tsunami earthquake. Geophysical Journal International, 186(2), 775781.

Nichol, S. L., Lian, O. B., \& Carter, C. H. (2003). Sheet-gravel evidence for a late Holocene tsunami run-up on beach dunes, Great Barrier Island, New Zealand. Sedimentary Geology, 155(1-2), 129-145.

Nichol, S. L., Goff, J., Devoy, R. J., Chagué-Goff, C., Hayward, B., \& James, I. (2007). Lagoon subsidence and tsunami on the West Coast of New Zealand. Sedimentary Geology, 200(3-4), 248-262.

Nunn, P. D., Heorake, T., Tegu, E. T., Oloni, B., Simeon, K. A., Wini, L., Usuramo, S. L. M., \& Geraghty, P. (2006). Geohazards revealed by myths in the Pacific: a study of islands that have disappeared in Solomon Islands. South Pacific Studies, 27, 37-49.

Petchey, F., Spriggs, M., Bedford, S., Valentin, F., \& Buckley, H. (2014). Radiocarbon dating of burials from the Teouma Lapita cemetery, Efate, Vanuatu. Journal of Archaeological Science, 50, 227-242.

Phillips, B., Neal, D., Wikle, T., Subanthore, A., \& Hyrapiet, S. (2008). Mass fatality management after the Indian Ocean tsunami. Disaster Prevention and Management: An International Journal, 17(5), 681-697.

Prendergast, F. (2016). Interpreting megalithic tomb orientation and siting within broader cultural contexts. Journal of Physics: Conference Series, 685, 012004.

RCAHMS. (2017a). General oblique aerial view of the southern flank of Gallow Hill, Unst, looking E. RCAHMS Aerial Photography Digital, Catalogue No. DP 082030. http://canmore.org.uk/collection/1202880. Accessed 27 August 2017.

RCAHMS. (2017b). Oblique aerial view centred on the remains of the chambered cairn at Point of Cott with Cott farmstead adjacent, taken from the ENE. RCAHMS Aerial Photography Digital, Catalogue No. DP 060173. http://canmore.org.uk/collection/1144581. Accessed 27 August 2017.

Regnauld, H., Nichol, S., Goff, J., \& Fontugne, M. (2004). Maoris, tsunami, middens and Dune front accretion rate on the northeast coast of New Zealand: resilience of tsunami driven coastal features. Maoris, dépôts alimentaires et taux d' accrétion du front dunaire sur la côte nord est de la Nouvelle Zélande: adaptabilité d'accumulations cotières liées à un tsunami. Geomorphologie: Relief, Processus, Environnement, 1, 4554.

Reilly, S. (2003). Processing the dead in Neolithic Orkney. Oxford Journal of Archaeology, 22(2), $133-154$.

Renfrew, A. C., Harkness, D., \& Switsur, R. (1976). Quanterness, radiocarbon and the Orkney cairns. Antiquity, 50, 197-203.

Ritchie, P. R. (1961). A chambered cairn at Isbister, south Ronaldshay, Orkney. Proceedings of the Society of Antiquaries of Scotland, 92, 25-32.

Rutty, G. N., Byard, R. W., \& Tsokos, M. (2005). The tsunami. Forensic Science, Medicine, and Pathology, 1(1), 3-7.

Sahal, A., \& Lemahieu, A. (2011). The 1979 Nice airport tsunami: mapping of the flood in Antibes. Natural Hazards, 56(3), 833-840.

Sahlins, M. D. (1957). Differentiation by adaptation in Polynesian societies. The Journal of the Polynesian Society, 66, 291-300.

Saino, H. (2012). Hakkutsu-tyosa de kensyutsusareta Sendai Heiya no tsunami konseki [Excavated evidence of tsunamis in Sendai plain]. Quarterly of Archaeological Studies, 2012(232), 6-11.

Saino, H. (2015). Tsunami disasters of Yayoi period and Heian period in the Sendai Plain. Proceedings of the Symposium on Traces and Experiences of Past Tsunami Disasters in the Pacific Rim, and the Succession of Knowledge. Sendai: UN World Conference on Disaster Risk Reduction.

Sato, H., Shimamoto, T., Tsutsumi, A., \& Kawamoto, E. (1995). Onshore tsunami deposits caused by the 1993 Southwest Hokkaido and 1983 Japan Sea earthquakes. Pure Applied Geophysics, 144(3-4), 693-717.

Schulting, R., Sheridan, A., Crozier, R., \& Murphy, E. (2010). Revisiting Quanterness: new AMS dates and stable isotope data from an Orcadian chamber tomb. Proceedings of the Society of Antiquaries of Scotland, 140, 1-50.

Seike, K., Shirai, K., \& Kogure, Y. (2013). Disturbance of shallow marine soft-bottom environments and megabenthos assemblages by a huge tsunami induced by the 2011 M9.0 Tohoku-Oki earthquake. PLoS One, 8(6), e65417.

Sheridan, A. (2012). Neolithic Shetland: a view from the "mainland". In D. L. Mahler (Ed.), The border of farming and the cultural markers (pp. 6-36). Short papers from the network meeting in Lerwick, Shetland, Sept 5th-9th 2011). Copenhagen: The National Museum of Denmark.

Smith, D. E., Shi, S., Cullingford, R. A., Dawson, A. G., Dawson, S., Firth, C. R., Foster, I. D., Fretwell, P. T., Haggart, B. A., Holloway, L. K., \& Long, D. (2004). The Holocene storegga slide tsunami in the United Kingdom. Quaternary Science Reviews, 23(23-24), 2291-2321. 
Smits, G. (2011). Danger in the lowground: historical context for the March 11, 2011 Tōhoku Earthquake and Tsunami 低地の危険性一- 2011 年 3 月 11 日東北 大地震と津波の歴史的背景. The Asia-Pacific Journal, Japan Focus Volume, 9, 1-16.

Soloviev, S. L., Solovieva, O. N., Go, C. N., Kim, K. S., \& Shchetnikov, N. A. (2000). Tsunamis in the Mediterranean Sea 2000 BC-2000 AD (pp. 243). Dordrecht: Kluwer Academic.

Sorrel, P., Debret, M., Billeaud, I., Jaccard, S. L., McManus, J. F., \& Tessier, B. (2012). Persistent non-solar forcing of Holocene storm dynamics in coastal sedimentary archives. Nature Geoscience, 5(12), 892-896.

Suppasri, A., Muhari, A., Ranasinghe, P., Mas, E., Shuto, N., Imamura, F., \& Koshimura, S. (2012). Damage and reconstruction after the 2004 Indian Ocean tsunami and the 2011 Great East Japan tsunami. Journal of Natural Disaster Science, 34(1), 19-39.

Szczuciński, W. (2012). The post-depositional changes of the onshore 2004 tsunami deposits on the Andaman Sea coast of Thailand. Natural Hazards, 60(1), 115-133.

Tate, R. (1886). Report of Zetland anthropological expedition. Memoirs read before the Anthropological Society of London 1865-6. Anthropological Society of London, 2, 339-347.

Tilling, R. I., Koyanagi, R. Y., Lipman, P. W., Lockwood, J. P., Moore, J. G., \& Swanson, D. W. (1976). Earthquake and related catastrophic events island of Hawaii, November 29, 1975: a preliminary report. USGS Circular, 740, 1-33.

Triantaphyllou, S., \& Bessios, M. (2005). A mass burial at fourth century BC Pydna, Macedonia, Greece: evidence for slavery? Antiquity, 79(305). Project Gallery: http://www.antiquity.ac. uk/projgall/triantaphyllou305/.

Valentin, F., Bedford, S., Buckley, H. R., \& Spriggs, M. (2010). Lapita burial practices: evidence for complex body and bone treatment at the Teouma cemetery, Vanuatu, Southwest Pacific. Journal of Island and Coastal Archaeology, 5(2), 212-235.

Valentin, F., Spriggs, M., Bedford, S., \& Buckley, H. (2011). Vanuatu mortuary practices over three millennia: Lapita to the early European contact period. Journal of Pacific Archaeology, 2, 49-65.

Villa, P., Bouville, C., Courtin, J. E., Helmer, D. A., Mahieu, E. R., Shipman, P., Belluomini, G. I., \& Branca, M. A. (1986). Cannibalism in the Neolithic. Science, 233(4762), 431-437.

Vinayak, V., Goyal, M. K., Mishra, V., \& Rai, A. (2010). Diatoms as a great forensic tool in investigation of deaths due to drowning: a case study. Journal of Forensic Medicine and Toxicology, 27, 51-54.

Waddington, C., \& Wicks, K. (2017). Resilience or wipe out? Evaluating the convergent impacts of the $8.2 \mathrm{ka}$ event and Storegga tsunami on the Mesolithic of northeast Britain. Journal of Archaeological Science, 14, 692-714.

Walsh, S. L., Knüsel, C. J., \& Melton, N. D. (2012). A re-appraisal of the Early Neolithic human remains excavated at Sumburgh, Shetland in 1977. Proceedings of the Society of Antiquaries of Scotland, 141, 317.

Whittle, A., Barclay, A., Bayliss, A., McFadyen, L., Schulting, R., \& Wysocki, M. (2007). Building for the dead: events, processes and changing worldviews from the thirty-eighth to the thirty-fourth centuries cal. BC in southern Britain. Cambridge Archaeological Journal, 17(S1), 123-147.

Wicks, K., \& Mithen, S. J. (2014). The impact of the abrupt $8.2 \mathrm{Ka}$ cold event on the Mesolithic population of western Scotland. Journal of Archaeological Science, 45, 240-269.

Williams, S., Goff, J., Ah Kau, J., Sale, F., Chagué-Goff, C., \& Davies, T. (2013). Geological investigation of palaeotsunamis in the Samoan islands: interim field report and research directions. Science of Tsunami Hazards, 32, 156-175.

Yagishita, K. (2001). Transportation and sedimentation of beach and sea-floor gravels caused by tsunami. Journal of Geography (Chigaku Zasshi), 110(5), 689-697.

Yamada, Y., Kawamura, K., Ikehara, K., Ogawa, Y., Urgeles, R., Mosher, D., Chaytor, J., \& Strasser, M. (2012). Submarine mass movements and their consequences chapter 1. In Y. Yamada, K. Kawamura, K. Ikehara, Y. Ogawa, R. Urgeles, D. Mosher, J. Chaytor, \& M. Strasser (Eds.), Submarine mass movements and their consequences: 5th international symposium (pp. 1-12). Berlin: Springer Science and Business Media. 